\title{
WORKING
}

paper

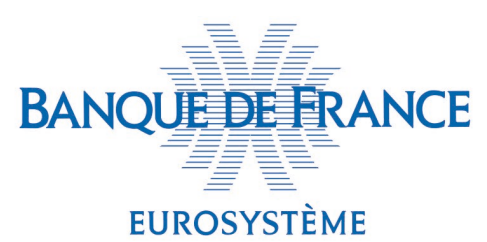

EUROSYSTÈME

\section{The Global Financial Cycle and US Monetary Policy in an Interconnected World}

\author{
Stéphane Dées ${ }^{1}$ and Alessandro Galesi ${ }^{2}$
}

November 2019, WP \#744

\begin{abstract}
We assess the international spillovers of US monetary policy with a large-scale global VAR which models the world economy as a network of interdependent countries. An expansionary US monetary policy shock contributes to the emergence of a Global Financial Cycle, which boosts macroeconomic activity worldwide. We also find that economies with floating exchange rate regimes are not fully insulated from US monetary policy shocks and, even though they appear to be relatively less affected by the shocks, the differences in responses across exchange rate regimes are not statistically significant. The role of US monetary policy in driving these macrofinancial spillovers gets even reinforced by the complex network of interactions across countries, to the extent that network effects roughly double the direct impacts of US monetary policy surprises on international equity prices, capital flows, and global growth.
\end{abstract}

Keywords: Trilemma, Global Financial Cycle, Monetary Policy Spillovers, Network Effects

JEL classification: C32; E52; F40

\footnotetext{
${ }^{1}$ Banque de France and Univ. Bordeaux. Stephane.dees@banque-france.fr

${ }^{2}$ Banco de España, alessandro.galesi@,bde.es

We thank our discussants Jean-Pierre Allegret, Sophie Brana, Martin Feldkircher and Jenny Xu, as well as participants at the XVI ESCB Emerging Markets Workshop (Rome), the 6th SAFE International Conference on Sovereign Bond Markets "Quantitative Easing and Financial Instability" (Frankfurt), the 7th ABFER Annual Conference (Singapore), the 68th Annual Meeting of the French Economic Association (Orleans) as well as at the seminars at Banque de France, Banco de España and the University of Bordeaux for useful comments.
}

Working Papers reflect the opinions of the authors and do not necessarily express the views of the Banque de France. This document is available on publications.banque-france.fr/en 


\section{NON-TECHNICAL SUMMARY}

The literature has traditionally emphasized that economies with a flexible exchange rate regime are more insulated than those which constrain their monetary policy to pegging their exchange rate to a reference currency. This reflects the classical Mundellian Trilemma according to which a country can attain just two of three objectives among exchange rate stability, free capital mobility, and independent monetary policy. The Trilemma has been recently put into question, as a US monetary policy shock is found to trigger an extraordinarily high comovement in international financial variables - a Global Financial Cycle - which affects the monetary conditions of any economy regardless of its exchange rate regime.

This paper aims at quantifying the effects of US monetary policy shocks on the rest of the world. In particular, it measures to what extent the role of US monetary policy in driving the Global Financial Cycle gets amplified by the complex network of cross-country interactions that arise in a highly integrated global economy. We tackle this question by assessing the international spillovers of US monetary policy with an estimated global VAR (GVAR), a multi-country empirical framework which models the global economy as a network of interdependent countries which account altogether for more than $90 \%$ of world GDP. Each economy in the GVAR is represented by a VAR model that includes both domestic and economy-specific external variables, where the latter are meant to reflect the relative importance of the other countries for the given economy. By allowing for heterogeneity across economies we can obtain the full distribution of country-specific spillover effects rather than a single point for the aggregate.

The model allows to investigate whether the effects of US monetary policy shocks get amplified by the complex network of interactions among receiver countries, as well as by spillback effects from countries in the rest of the world to the US. We identify US monetary policy shocks using theory-based sign restrictions on selected responses of US variables, while at the same time leaving unrestricted the responses of all variables in the rest of countries so to allow for an agnostic identification strategy about the size and sign of international spillovers. We explicitly consider both conventional and unconventional monetary policy measures, so to provide a comprehensive picture of US monetary policy actions.

We show that unexpected expansionary US monetary policy surprises contribute to the emergence of a Global Financial Cycle that boosts macroeconomic activity worldwide, regardless of whether the monetary easing is achieved by a conventional drop in the policy rate or by a compression of the yield spread. Importantly, macro-financial spillovers are economically and statistically significant even in economies with floating exchange rate regimes and, if anything, having a flexible exchange rate provides just a partial insulation to foreign shocks.

Our results are consistent with the idea that shifts in monetary policy of the hegemon economy, the United States, generate a global synchronization of financial variables which affects all countries altogether. Importantly though, we also show that the role- of US monetary policy in driving these macro-financial spillovers gets even reinforced by network effects, which roughly double the direct impacts of US monetary policy surprises on international equity prices, capital flows, and global growth. We also document that this amplification increases as countries get more globally integrated over time, suggesting that the evolution of the network is an important driver of the increasing role of US monetary policy in shaping the Global Financial Cycle. 


\section{The role of the network for domestic and spillover effects}
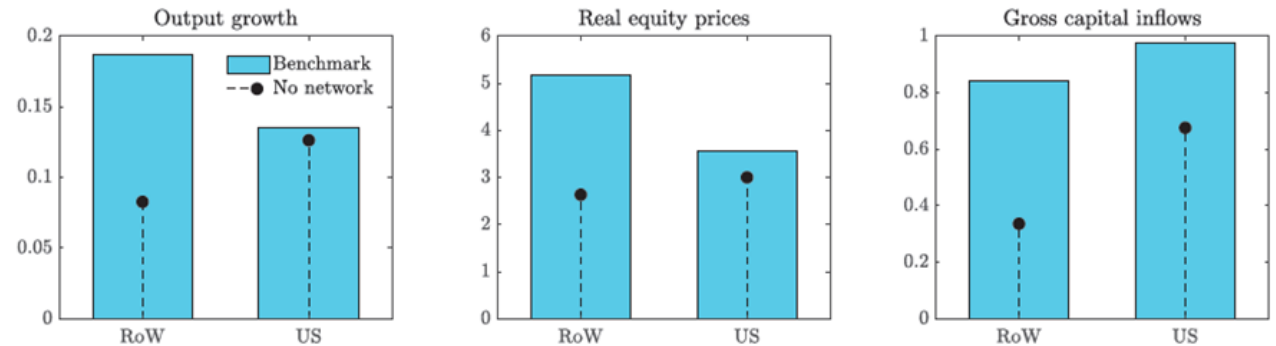

(a) Drop of US policy rate
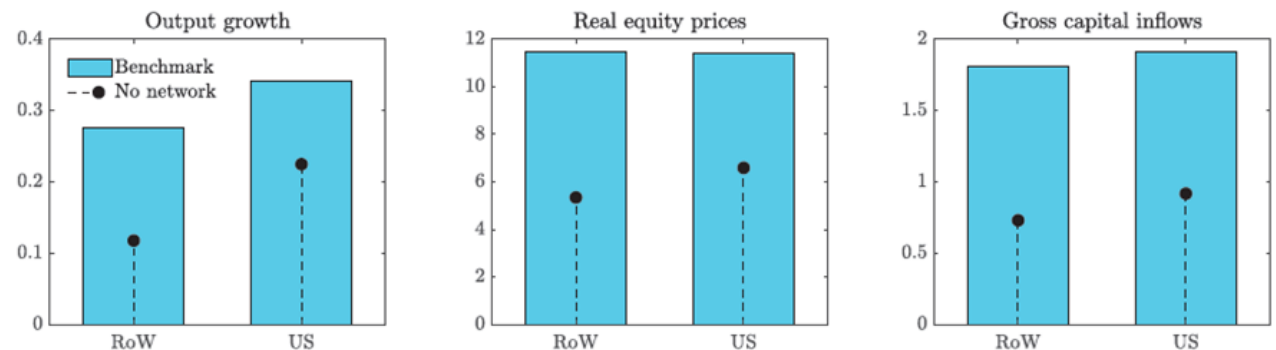

(b) Compression of US term spread

Notes: average one-year effects for the rest of the world (RoW) and United States to a US monetary policy shock which decreases either the US short-term rate by 25 b.p. (panel a), or the US term spread by 25 b.p. (panel b). Benchmark: baseline model with network effects; No network: the shocks affect all countries, but excludes third-country and second-round effects. y axes measure percentage points.

\section{Le cycle financier mondial et la politique monétaire des États-Unis dans un monde interconnecté}

\section{RÉSUMÉ}

Nous évaluons les retombées internationales de la politique monétaire des Etats-Unis à l'aide d'un GVAR qui modélise l'économie mondiale comme un réseau de pays interdépendants. Un choc expansionniste de la politique monétaire américaine contribue à l'émergence d'un cycle financier mondial, qui stimule l'activité macroéconomique mondiale. Nous constatons également que les économies à régime de changes flottants ne sont pas entièrement à l'abri des chocs de politique monétaire aux États-Unis et que, même si elles semblent relativement moins touchées par ces chocs, les différences de réaction entre les régimes de changes ne sont pas statistiquement significatives. Le rôle de la politique monétaire américaine dans ces retombées macrofinancières est encore renforcé par le réseau complexe d'interactions entre les pays, à tel point que les effets de réseau doublent à peu près les effets directs des surprises de la politique monétaire américaine sur les cours des actions internationales, les flux de capitaux et la croissance mondiale.

Mots-clés : Trilemme, Cycle Financier Mondial, Retombées de la Politique Monétaire, Effets de Réseau

Les Documents de travail reflètent les idées personnelles de leurs auteurs et n'expriment pas nécessairement la position de la Banque de France. Ils sont disponibles sur publications.banque-france.fr 


\section{Introduction}

The literature on the international transmission of monetary policy has traditionally emphasized that economies with a flexible exchange rate regime are more insulated than those which constrain their monetary policy to pegging their exchange rate to a reference currency, a reflection of the classical Mundellian Trilemma according to which a country can attain just two of three objectives among exchange rate stability, free capital mobility, and independent monetary policy. ${ }^{1}$ The Trilemma has been recently put into question by Rey (2013) and subsequently Miranda-Agrippino and Rey (2019), which document that US monetary policy triggers an extraordinarily high comovement in international financial variables - a Global Financial Cycle - which affects the monetary conditions of any economy regardless of its exchange rate regime, as long as cross-border capital flows are free and macroprudential policies are not employed.

Consistently with the logic of the Global Financial Cycle, the communication of the Fed explicitly recognizes the relevant role of its actions in affecting the global economy and, importantly, it recurrently emphasizes the importance of assessing potential spillback effects from its own policies. This point has been made clear for instance by the former Vice Chairman of the Federal Reserve, Mr. Stanley Fischer,

"And of course, actions taken by the Federal Reserve influence economic conditions abroad. Because these international effects in turn spill back on the evolution of the U.S. economy, we cannot make sensible monetary policy choices without taking them into account." Fischer (2014)

Since US monetary policy endogenously responds to the global consequences of its own measures, ${ }^{2}$ the natural question is to what extent the role of US monetary policy in driv-

\footnotetext{
${ }^{1}$ See for instance Mundell (1963) and Obstfeld et al. (2005). In this context, Shambaugh (2004), Obstfeld et al. (2019), and several references therein have shown that countries with flexible exchange rates feature short-term interest rates which correlate less with the base country interest rates.

${ }^{2}$ In the context of monetary policies of advanced economies, a similar argument has been made by Shin (2015): "There is much talk of "headwinds" from emerging markets buffeting the advanced economies, but the tendency is to speak of these headwinds as if they had come out of the blue... ...these headwinds are the result of monetary policy actions taken some time ago, in the emerging market economies but also by precisely those advanced economies being buffeted by these headwinds", and by Carney (2019): "And while it is unrealistic to expect advanced economy policymakers to internalise fully spillovers from their
} 
ing the Global Financial Cycle gets amplified by spillback effects and, more generally, by the complex network of cross-country interactions that arise in a highly integrated global economy. ${ }^{3}$ We tackle this question by assessing the international spillovers of US monetary policy with an estimated global VAR (GVAR), a multi-country empirical framework which models the global economy as a network of interdependent countries which account altogether for more than $90 \%$ of world GDP. The model allows to investigate whether the effects of US monetary policy shocks get amplified by the complex network of interactions among receiver countries, as well as by spillback effects from countries in the rest of the world to the US. We identify US monetary policy shocks using theory-based sign restrictions on selected responses of US variables, while at the same time leaving unrestricted the responses of all variables in the rest of countries so to allow for an agnostic identification strategy about the size and sign of international spillovers. We explicitly consider both conventional and unconventional monetary policy measures, the latter intended as a broad mix of measures and communication aimed at affecting the yield spread while leaving at the same time the policy rate unchanged in the spirit of Baumeister and Benati (2013), so to provide a comprehensive picture of US monetary policy actions.

We show that unexpected expansionary US monetary policy surprises contribute to the emergence of a Global Financial Cycle that boosts macroeconomic activity worldwide, regardless of whether the monetary easing is achieved by a conventional drop in the policy rate or by a compression of the yield spread. Importantly, macro-financial spillovers are economically and statistically significant even in economies with floating exchange rate regimes and, if anything, having a flexible exchange rate provides just a partial insulation to foreign shocks. Bringing support to recent findings in Miranda-Agrippino and Rey (2019), our results are consistent with the idea that shifts in monetary policy of the hegemon economy, the United States, generate a global synchronization of financial variables which affects all countries altogether. Importantly though, we also show that the role

actions on emerging markets, given their domestic mandates, advanced economies monetary policies will increasingly need to take account of spillbacks".

${ }^{3}$ In this respect, Obstfeld (2019) argue that the particular structure of international financial markets implies that the actions of the Federal Reserve are likely to propagate powerfully abroad, with important potential spillbacks onto the US economy itself. 
of US monetary policy in driving these macro-financial spillovers gets even reinforced by network effects, which roughly double the direct impacts of US monetary policy surprises on international equity prices, capital flows, and global growth. We also document that this amplification increases as countries get more globally integrated over time, suggesting that the evolution of the network is an important driver of the increasing role of US monetary policy in shaping the Global Financial Cycle.

As anticipated, our results are closely related to the recent work by Miranda-Agrippino and Rey (2019), which find evidence of powerful financial spillovers of US monetary policy to the rest of the world, even in those countries with a floating exchange rate regime. They reach to this conclusion by estimating a large-scale Bayesian VAR which includes several macro-financial indicators for the US, as well as several equivalent indicators for the world (or alternatively, for the subset of independently floating exchange rate countries), the latter computed as cross-sectional sums of country-specific variables. While this study treats the rest of the world as a homogeneous economy, we explicitly model it as the conglomerate of interconnected heterogeneous economies. In particular, each economy in the GVAR is represented by a VAR model that includes both domestic and economy-specific external variables, where the latter are meant to reflect the relative importance of the other countries for the given economy. By allowing for heterogeneity across economies we can obtain the full distribution of country-specific spillover effects rather than a single point for the aggregate. But more importantly, by allowing for connections among economies we find that the network is a relevant amplifier of the US monetary impulse, for both domestic and spillover effects. Our result is consistent with recent analysis in Georgiadis (2017), which shows that abstracting from higher-order transmission channels induced by interactions among countries may lead to underestimated spillovers. In this respect, Dedola et al. (2017) employ a two-step strategy which consists of estimating first the US monetary policy shock, identified via theory-based sign restrictions, using a large-scale Bayesian VAR including US and global (aggregate) variables, then running batteries of independent country- and variable-specific regressions on the estimated shock. This paper finds sizable macro-financial spillovers of US monetary policy, and no clear-cut systematic relation between country responses and the exchange rate flexibility. While 
confirming these results, we show that accounting for interdependencies across countries provides a more powerful picture of US monetary policy regarding the magnitude of its estimated effects. ${ }^{4}$

Our empirical approach is closer to research which has already successfully employed GVAR models to study the international transmission of US monetary policy shocks, the latter being typically identified using sign restrictions on impulse responses as in our analysis. Georgiadis (2016) finds that an unexpected US monetary policy tightening significantly depresses output globally, spillovers for some countries are even larger than domestic effects, and economies with a floating exchange rate feature smaller effects. Also using the same framework, Feldkircher and Huber (2016) compares spillovers stemming from demand, supply, and monetary policy of the US, and find that a monetary policy tightening produces particularly negative output effects across countries. Chen et al. (2016) also employ a GVAR to show that US Quantitative Easing measures, proxied by reductions in the US term and corporate spreads identified via recursive Cholesky schemes, prevented the US and other advanced economies from prolonged recession and deflation, and that spillover effects are particularly large in emerging economies. While broadly confirming results of these studies, our novel contribution is to document that these global macroeconomic spillovers are intrinsically connected with the emergence of a Global Financial Cycle, which stems from the US monetary policy surprise and strengthens via the global network, with important spillback effects onto the US economy itself.

The structure of the paper is as follows. Section 2 describes the empirical setup: the GVAR model, the data and the specification of the model, the identification strategy, and the estimation. Section 3 presents the results of the analysis. Section 4 concludes.

\footnotetext{
${ }^{4}$ In the same vein, Burriel and Galesi (2018) find for the euro area that the effects of unconventional monetary policy measures are substantially lower when not accounting for interactions among members of the currency union. Our finding about the relevance of worldwide network effects also connects with Ehrmann and Fratzscher (2009) which analyze the transmission of US monetary policy shocks to global equity markets and find that what determines the magnitude of transmission is not a country's bilateral integration with the United States, but rather its global integration vis-ïji-vis all other countries.
} 


\section{Empirical Methodology}

\subsection{The GVAR Model}

The analysis is based on the GVAR modeling framework as firstly developed in Pesaran et al. (2004) and further extended in Dées et al. (2007). The GVAR model is a system of national VAR models in which cross-country interactions are explicitly taken into account. Being a multi-country model, the GVAR deals with country heterogeneities in a simple and effective way, thus allowing for assessing asymmetries in the international transmission of monetary policy shocks. Specifically, each national economy $i$ is modeled as a $\operatorname{VARX}\left(p_{i}, q_{i}\right)$,

$$
Y_{i t}=a_{i}+b_{i} t+\sum_{j=1}^{p_{i}} A_{i j} Y_{i, t-j}+\sum_{j=0}^{q_{i}} B_{i j} Y_{i, t-j}^{*}+\sum_{j=0}^{q_{i}} C_{i j} X_{t-j}+u_{i t}
$$

where $a_{i}$ and $b_{i}$ are vectors of variable-specific coefficients associated to a constant and a time trend, respectively; $A_{i j}, B_{i j}$, and $C_{i j}$ are matrices of coefficients; and $u_{i t}$ is a vector of idiosyncratic country-specific shocks which are assumed to be serially uncorrelated zeromean processes with full variance-covariance matrix $\Sigma_{i i}$. The vector $Y_{i t}$ includes domestic variables which represent the domestic macro-financial conditions of the economy. The vector $Y_{i t}^{*}$ contains country-specific foreign variables which capture, for each economy $i$, the influence of its main economic partners. These variables are calculated as crosssectional averages of the corresponding domestic variables of the other $j$ countries,

$$
Y_{i t}^{*}=\sum_{j \neq i} w_{i j} Y_{j t} \quad \text { with } \quad \sum_{j \neq i} w_{i j}=1
$$

where weights $w_{i j}$ are generally based on bilateral trade flows or alternatively on bilateral measures of financial exposure. ${ }^{5}$ The vector $X_{t}$ includes global variables which affect all countries at the same time, such as oil prices. Global variables follow the process

$$
X_{t}=a_{x}+b_{x} t+\sum_{j=1}^{p_{x}} D_{j} X_{t-j}+\sum_{j=0}^{q_{x}} F_{j} \tilde{Y}_{t-j}+u_{x t}
$$

\footnotetext{
${ }^{5}$ Being constructed as cross-sectional averages, country-specific foreign variables allow to overcome the curse of dimensionality that would occur if variables of each individual foreign country had to be included. In practice, foreign variables resemble factors extracted by statistical dimension-reduction techniques such as in Forni et al. (2000) and Stock and Watson (2002), but where loading coefficients are known and informed by data on trade or financial flows.
} 
where $a_{x}$ and $b_{x}$ are vectors of coefficients associated to a constant and a time trend; $D_{j}$ and $F_{j}$ are matrices of coefficients; and $u_{x t}$ is a vector of reduced form residuals which are assumed to be serially uncorrelated zero-mean processes with full variance-covariance matrix $\Sigma_{x x}$. The vector $\tilde{Y}_{t}$ is composed by weighted averages of all countries' domestic variables, where weights are based on the relative importance of each country in the world economy (GDP shares), and capture the feedback effects from all countries to the global variables.

In this setting, the sets of foreign $\left(Y_{i t}^{*}\right)$ and global $\left(X_{t}\right)$ variables capture the external dimension of each economy and channel the effects of foreign shocks, such as a US monetary policy surprise, onto the domestic macro-financial conditions. In this respect, it is worth noticing that the specification in (1) is flexible enough to embed simpler frameworks. For instance, cross-country bilateral interactions can be precluded by setting to zero the weight of any foreign economy $j$ with respect to each country $i, w_{i j}=0$, so that the set of country-specific foreign variables disappears from (1). By additionally setting to unity each economy-specific weight with respect to the US, $w_{i, U S}=1$, equation (2) implies that the foreign variables of each given economy $i$ coincide with the US variables, $Y_{i t}^{*}=Y_{U S, t}$. Hence in this case a US monetary policy shock affects other countries just directly, in the sense that the shock does not propagate via bilateral interactions among countries in the rest of the world. This specification is typically employed in the literature, see for instance Dedola et al. (2017) and Iacoviello and Navarro (2019), and we will explicitly compare results from such a setting when assessing the role of the network as amplifier of the US monetary impulse.

In order to obtain the final representation of the GVAR, we can exploit the fact that country-specific foreign variables are linear combinations of the endogenous variables, $Y_{i t}^{*}=W_{i} Y_{t}$, where $Y_{t}=\left(Y_{1 t}^{\prime}, \ldots, Y_{N t}^{\prime}\right)^{\prime}$ and $W_{i}$ are country-specific matrices based on weights $w_{i j}$ which capture interconnections across countries. Hence we can write each country-specific model as

$$
G_{i 0} Y_{t}=a_{i}+b_{i} t+\sum_{j=1}^{p_{i}} G_{i j} Y_{t-j}+\sum_{j=0}^{q_{i}} C_{i j} X_{t-j}+u_{i t}
$$

where $G_{i 0}=\left(I-B_{i 0} W_{i}\right)$ and $G_{i j}=\left(A_{i j}+B_{i j} W_{i}\right)$. We can then stack all country-specific 
models to obtain

$$
G_{0} Y_{t}=a+b t+\sum_{j=1}^{p} G_{j} Y_{t-j}+\sum_{j=0}^{q} C_{j} X_{t-j}+u_{t}
$$

where $u_{t}=\left(u_{1 t}^{\prime}, \ldots, u_{N t}^{\prime}\right)^{\prime}, G_{0}=\left(G_{10}^{\prime}, \ldots, G_{N 0}^{\prime}\right)^{\prime}, a=\left(a_{1}^{\prime}, \ldots, a_{N}^{\prime}\right)^{\prime}, b=\left(b_{1}^{\prime}, \ldots, b_{N}^{\prime}\right)^{\prime}$, $G_{j}=\left(G_{1 j}^{\prime}, \ldots, G_{N j}^{\prime}\right)^{\prime}, C_{j}=\left(C_{1 j}^{\prime}, \ldots, C_{N j}^{\prime}\right)^{\prime}, p=\max \left(p_{i}\right)$, and $q=\max \left(q_{i}\right)$.

Moreover, given that the feedback variables are GDP-based weighted averages of the country-specific variables, $\tilde{Y}_{t}=\tilde{W} Y_{t}$, where $\tilde{W}$ is a matrix defined by the GDP shares, we can write the GVAR as

$$
H_{0} Z_{t}=h_{0}+h_{1} t+\sum_{j=1}^{p} H_{j} Z_{t-j}+e_{t}
$$

where the vector $Z_{t}=\left(Y_{t}^{\prime}, X_{t}^{\prime}\right)^{\prime}$ includes all country-specific and common variables, and $H_{0}=\left[\begin{array}{cc}G_{0} & -C_{0} \\ -F_{0} \tilde{W} & I\end{array}\right], \quad h_{0}=\left[\begin{array}{c}a \\ a_{x}\end{array}\right], \quad h_{1}=\left[\begin{array}{c}b \\ b_{x}\end{array}\right], \quad H_{j}=\left[\begin{array}{cc}G_{j} & C_{j} \\ F_{j} \tilde{W} & D_{j}\end{array}\right], \quad e_{t}=\left[\begin{array}{c}u_{t} \\ u_{x t}\end{array}\right]$.

The vector $e_{t}=\left(u_{t}^{\prime}, u_{x t}^{\prime}\right)^{\prime}$ collects all residuals, with variance-covariance matrix $\Sigma$, defined by,

$$
\Sigma=\left[\begin{array}{ccccc}
\Sigma_{11} & \Sigma_{12} & \cdots & \Sigma_{1 N} & \Sigma_{1 x} \\
\Sigma_{21} & \Sigma_{22} & \cdots & \Sigma_{2 N} & \Sigma_{2 x} \\
\vdots & \vdots & \ddots & \vdots & \vdots \\
\Sigma_{N 1} & \Sigma_{N 2} & \cdots & \Sigma_{N N} & \Sigma_{N x} \\
\Sigma_{x 1} & \Sigma_{x 2} & \cdots & \Sigma_{x N} & \Sigma_{x x}
\end{array}\right]
$$

where cross-country covariances $\Sigma_{i j}$ are defined as $\Sigma_{i j}=\operatorname{cov}\left(u_{i t}, u_{j t}\right)=E\left(u_{i t} u_{j t}^{\prime}\right)$ and a typical element of $\Sigma_{i j}$, denoted by $\sigma_{i j, l s}$, measures the covariance of the $l$ th variable in country $i$ with the $s$ th variable in country $j .{ }^{6}$

Provided that the $H_{0}$ matrix is invertible, we can obtain the $\operatorname{GVAR}(p)$ in its reduced form,

$$
Z_{t}=k_{0}+k_{1} t+\sum_{j=1}^{p} K_{j} Z_{t-j}+v_{t}
$$

where $k_{0}=H_{0}^{-1} h_{0}, k_{1}=H_{0}^{-1} h_{1}, K_{j}=H_{0}^{-1} H_{j}$, and $v_{t}=H_{0}^{-1} e_{t}$ are reduced form shocks with zero mean and full variance-covariance matrix $\Omega=H_{0}^{-1} \Sigma\left(H_{0}^{-1}\right)^{\prime}$.

\footnotetext{
${ }^{6}$ Notice that country-specific shocks are allowed to be cross-sectionally correlated due to spatial or contagion effects that are not totally eliminated by the global and country-specific foreign variables. Nonetheless, as explained in Pesaran et al. (2004) residual cross-sectional correlation should be weak, a condition that we check after estimating the model.
} 
The dynamic properties of the global model are now determined by the $Z_{t}$ process, including impulse response functions. In this respect, we can express the reduced form shocks as a linear combination of structural shocks $\varepsilon_{t}$ so that $V \varepsilon_{t}=v_{t}$, where structural shocks are normalized to have unit variance $I=E\left(\varepsilon_{t} \varepsilon_{t}^{\prime}\right)$. This implies the restriction that $V V^{\prime}=\Omega$. In practice, we are interested in identifying two specific columns of $V$ which characterize the impact effects of unexpected conventional and unconventional monetary policy shocks stemming from the United States. To do so, we employ a combination of sign and zero restrictions as detailed in section 2.3.

\subsection{Data and Specification of the Model}

We consider a panel dataset of quarterly data, whose sample period spans from 1994Q1 to 2016Q4, for 33 countries which altogether account for more than 90\% of world GDP. The countries are listed in Table 1.

Table 1: Countries and Regions in the GVAR

$\begin{array}{lll}\begin{array}{ll}\text { Asia and Pacific } \\ \text { Australia }\end{array} & \begin{array}{l}\text { North America } \\ \text { Canada }\end{array} & \begin{array}{l}\text { Europe } \\ \text { China }\end{array} \\ \begin{array}{l}\text { India } \\ \text { Indoxico }\end{array} \\ \text { Japan } & \text { United States } & \text { Belgium* } \\ \text { Korea } & \text { South America } & \text { Finland* } \\ \text { Malaysia } & \text { Argentina } & \text { France* } \\ \text { New Zealand } & \text { Brazil } & \text { Italy* } \\ \text { Philippines } & \text { Chile } & \text { Netherlands* } \\ \text { Singapore } & \text { Peru } & \text { Norway } \\ \text { Thailand } & & \text { Spain* } \\ & \text { Africa and Middle East } & \text { Sweden } \\ & \text { Saudi Arabia } & \text { Swizerland } \\ & \text { South Africa } & \text { Turkey } \\ & & \text { United Kingdom }\end{array}$

Notes: countries marked by * are jointly modelled as a single euro area model.

Regarding the domestic variables $Y_{i t}$, we employ data on real GDP growth, CPI inflation, short-term interest rate at annual rate, the spread between long- and short-term 
interest rates, real equity prices, gross capital inflows over GDP, and the nominal effective exchange rate. Individual models do not include domestic credit flows and credit spreads, due to lack of available data for most of the countries. Conversely, international capital flows data are available for all countries in our sample, and gross (rather than net) inflows data are employed in order to focus on capital movements initiated by foreigners, in line with Forbes and Warnock (2012) and Miranda-Agrippino and Rey (2019). Moreover, capital inflows represent the foreign contribution to domestic credit dynamics, which matters the most when studying the international dimension of financial cycles. Finally, although the GVAR approach is meant to deal with the curse of dimensionality in large systems, the country-specific models need to remain relatively small to keep sufficient degrees of freedom for the estimation. Thus, the choice of variables is realized as a trade-off between a parsimonious specification and the coverage of various transmission mechanisms. As in Dées et al. (2007), we treat the euro area as a single model, by aggregating data of member countries using their relative GDP shares. ${ }^{7}$ Due to data limitations, some country models do not include some specific variables, and Table 4 in Appendix reports the data availability for each economy. Data for most of the variables come from the GVAR Quarterly Database recently updated in Mohaddes and Raissi (2018), which we complement with data from the OECD Main Economic Indicators for equity prices in Brazil, Mexico, and Turkey, while data for capital inflows come from the IMF Balance of Payments Statistics.

With respect to the country-specific foreign variables $Y_{i t}^{*}$ which capture potential interactions across countries, we consider country-specific weighted averages of trade partners' real GDP growth, CPI inflation, short-term interest rate, real equity prices, and term spread. Weights are computed using cross-country bilateral trade flows averaged over the period 1994-2016, where data are also available in the GVAR Quarterly Database of Mohaddes and Raissi (2018). Due to lack of reliable data across countries on bilateral measures of financial exposure, we do not explore an alternative specification with financial-based weights. In this respect, Eickmeier and Ng (2015) show that trade and

\footnotetext{
${ }^{7}$ It is possible to extend the original GVAR framework by allowing for mixed cross-sections in the spirit of Gross and Kok (2013). In particular, Georgiadis (2015) considers a mixed cross-section global VAR in which all euro area economies are included individually while, at the same time, their common monetary policy is modeled as a function of euro area aggregate variables.
} 
financial weights can be quite different for some countries, but they also document that the resulting foreign variables strongly correlate with factors obtained from common statistical dimension-reduction techniques regardless of the chosen weighting scheme. It is also worth pointing out that the choice of a weighting matrix based on trade weights does not preclude the presence of financial linkages since the model includes explicit interconnections among financial variables, which are meant to uncover the potential emergence of a global financial cycle. Moreover, a weighting matrix based on trade flows is particularly relevant to account for the increasing integration of emerging economies in the global economy as it remains mostly a trade-related phenomenon (e.g. the role of China as a major trading partner, or the transmission of shocks via global value chains). Finally, we include oil prices as global variable in $X_{t}$, which endogenously respond to developments of the world economy by including as feedback variables $\tilde{Y}_{t}$ the weighted averages of countrylevel output growth and inflation, where weights are based on GDP shares averaged over the period 1994-2016.

\subsection{Identification}

The strategy to identify exogenous US monetary policy shocks amounts to impose a combination of sign restrictions on impulse responses of selected US variables, following a minimal set of predictions implied by standard monetary theory. At the same time, the approach leaves unrestricted the responses of all variables of the rest of countries so to allow for an agnostic identification strategy about the size and sign of international spillovers.

To provide a comprehensive picture of US monetary policy actions, we explicitly consider not only conventional surprises in the policy rate, but also unconventional monetary policy measures, the latter intended as a broad mix of measures and communication aimed at affecting the yield spread while leaving at the same time the policy rate unchanged. ${ }^{8}$ The approach of distinguishing both types of measures follows the spirit of

\footnotetext{
${ }^{8}$ Woodford (2012) classifies unconventional measures into two broad categories: balance-sheet policies, according to which the central bank varies either the size or the composition of its balance sheet even in the absence of any change in its policy rate; and forward guidance, in terms of explicit statements about the outlook for future policy. Importantly, some of these measures have been employed by the Fed
} 
Baumeister and Benati (2013). On one hand, a conventional drop of the US short-term (policy) rate should boost domestic growth, inflation, and equity prices, and should lead to a depreciation of the US dollar vis-ï£j-vis the foreign currency. As the shock should be transitory, the yield curve steepens, the fall in the long-term rate being smaller than the corresponding fall in the short-term rate. On the other hand, an expansionary unconventional monetary policy shock which reduces the domestic term spread should also boost domestic growth, inflation, and equity prices, and should lead to a depreciation of the US dollar. ${ }^{9}$ However the shock should be orthogonal to the conventional monetary policy surprise, so that the US short-term interest rate should not respond on impact.

As shown in Table 2, these restrictions are sufficient to disentangle the two types of monetary policy shocks, thus achieving identification. Sign restrictions on US variables are imposed on impact and one period after the shock, whereas the responses of all variables in the rest of the countries are left unrestricted. The implementation of the sign and zero restrictions is based on the algorithm recently developed in Arias et al. (2018). ${ }^{10}$

well before the policy rate reached its effective lower bound. For instance, Gükaynak et al. (2005) and Campbell et al. (2012) find, respectively for the periods 1990-2004 and 1990-2007, that FOMC forward guidance announcements were able to shift expectations about the future path of the funds rate, and not simply through the announcement of a new current policy target.

${ }^{9}$ As discussed in Baumeister and Benati (2013), a flattening of the yield curve boosts output and inflation by removing duration risk and reducing borrowing costs for the private sector. Several empirical papers referenced therein provide supporting evidence to the existence of these transmission channels.

${ }^{10}$ Specifically, we draw 2000 orthonormal $Q$ matrices satisfying $V Q Q^{\prime} V^{\prime}=\Omega$ and store those draws which satisfy restrictions in Table 2. To reduce the computational burden, we have also experimented using 500 replications and results are virtually identical. To account for parameter uncertainty, we repeat the algorithm for each of 500 bootstrap replications of the GVAR. 
Table 2: Identification of US monetary policy shocks

\begin{tabular}{|c|c|c|c|c|}
\hline \multirow[b]{2}{*}{ Variable/Country: } & \multicolumn{2}{|c|}{ Conventional MP shock } & \multicolumn{2}{|c|}{ Unconventional MP shock } \\
\hline & United States & Other countries & United States & Other countries \\
\hline Short-term interest rate & - & $?$ & 0 & $?$ \\
\hline Term spread & + & $?$ & - & $?$ \\
\hline Inflation & + & $?$ & + & $?$ \\
\hline Output growth & + & $?$ & + & $?$ \\
\hline Real equity prices & + & $?$ & + & $?$ \\
\hline NEER & - & $?$ & - & $?$ \\
\hline Gross capital inflows & $?$ & $?$ & $?$ & $?$ \\
\hline Oil price & & $?$ & & $?$ \\
\hline
\end{tabular}

Notes: restrictions are imposed on impact and one period after the shock, ? indicates that the response is left unrestricted. A fall of US NEER indicates a depreciation of the US dollar vis-ï $j$-vis the foreign currency.

\subsection{Estimation}

The estimation of the model proceeds on a country-by-country basis as in Pesaran et al. (2004). ${ }^{11}$ Specifically, all country-specific models, as well as the model for oil prices, are estimated by least squares in their VARX form. ${ }^{12}$ For each country-specific model we choose a relatively parsimonious lag structure by setting the lag order of the endogenous variables, $p_{i}$, equal to one. The lag order of country-specific foreign and global variables, $q_{i}$, is also set equal to one. With respect to the model for oil prices, we fix the lag order of the endogenous variable $p_{x}$ equal to one. Similarly, we set the lag order of the feedback variables $q_{x}$ equal to one.

Despite the parsimonious lag structure, the model adequately captures the serial correlation of the modeled variables. The autocorrelation functions included in Panel (a) of Figure 1 indicate that most residuals are serially uncorrelated and therefore the model

\footnotetext{
${ }^{11}$ The direct estimation of equation (7) is unfeasible because of the large amount of parameters which greatly exceeds the number of available observations. In this respect, the country-by-country estimation allows for reducing the dimensionality of the model.

${ }^{12}$ Given the relatively short sample period, we abstract from explicitly identifying long-run relationships among variables, in line with Georgiadis (2016).
} 
captures most of the persistence in the data. In this respect, Panel (b) of Figure 1 shows that the absolute values of all the eigenvalues of the estimated GVAR's companion matrix stand below unity. This confirms that the model captures well the complex dynamics and interactions among variables, and at the same that it is dynamically stable, so that shocks tend to die out over time with some inertia.

The country-by-country estimation of the model's parameters hinges on the weak exogeneity of the foreign variables, which is a formalization of the concept of small open economy from an econometric perspective. Following Pesaran et al. (2004), we can indirectly check whether a number of sufficient conditions for this assumption to hold are verified in our setup. First, weights used in the construction of country-specific foreign variables should be small, in the sense that squared weights should tend to zero as the number of countries included in the GVAR increases. Panel (c) in Figure 1 reports the trade-based weights and shows that, with some exceptions, the vast majority of weights are small. The most notable exceptions refer to the weights of United States with respect to Canada and Mexico, those of the euro area with respect to Sweden, Switzerland, Turkey, and United Kingdom, as well as the weight of China with respect to South Korea. Second, there should be cross-sectional weak dependence, meaning that the cross-dependence of the idiosyncratic shocks is sufficiently small so that it tends to zero as the number of economies tends to infinity. Panel (d) in Figure 1 plots the cumulative density function of the pairwise correlations across the estimated residuals (in absolute value). Most of pairwise correlations are low, for instance about $90 \%$ of the mass lies below the $20 \%$ correlation level, hence this confirms that cross-sectional dependence is weak for most of residuals. 
Figure 1: Diagnostics of the estimated GVAR model

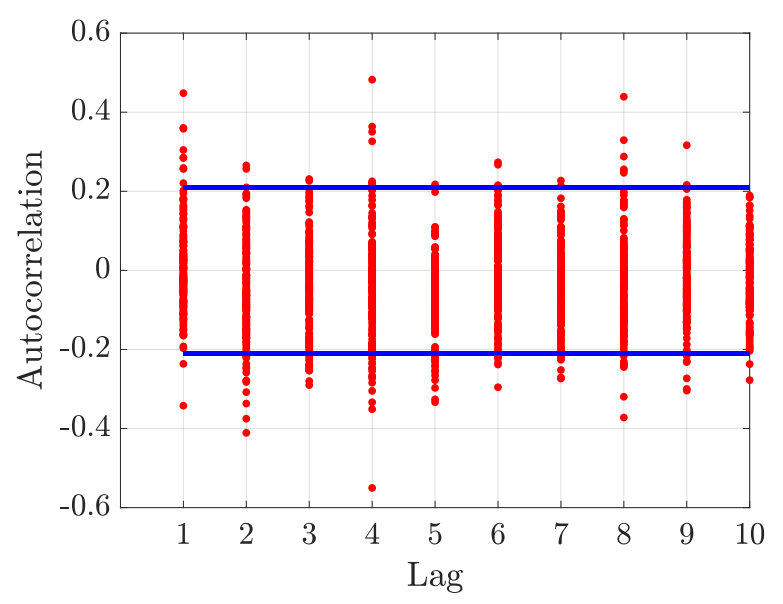

(a) Residual serial dependence

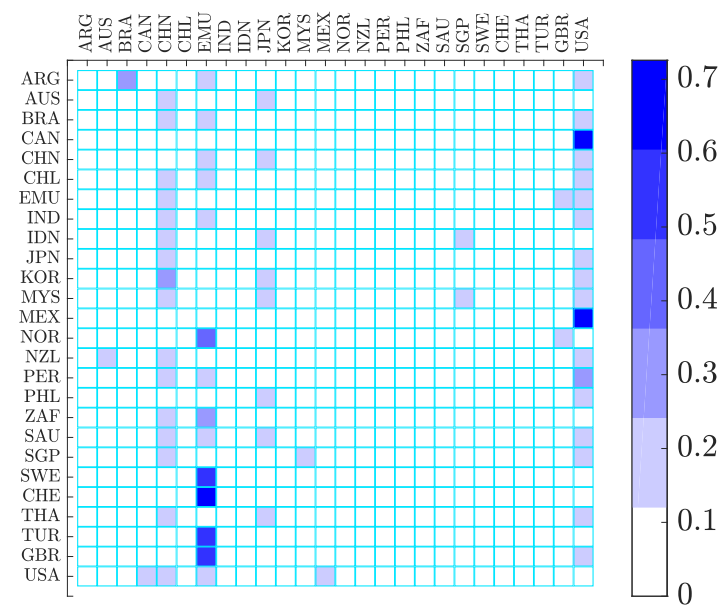

(c) Trade-based weights matrix

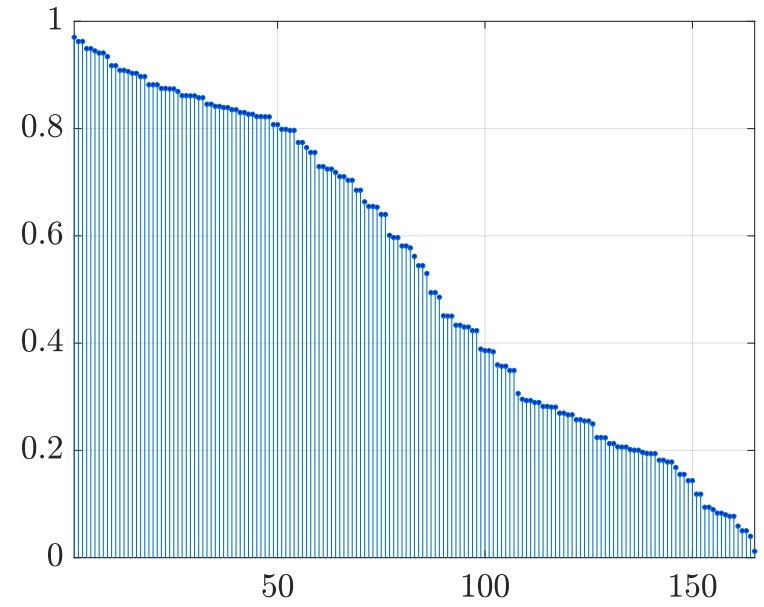

(b) Eigenvalues of the GVAR

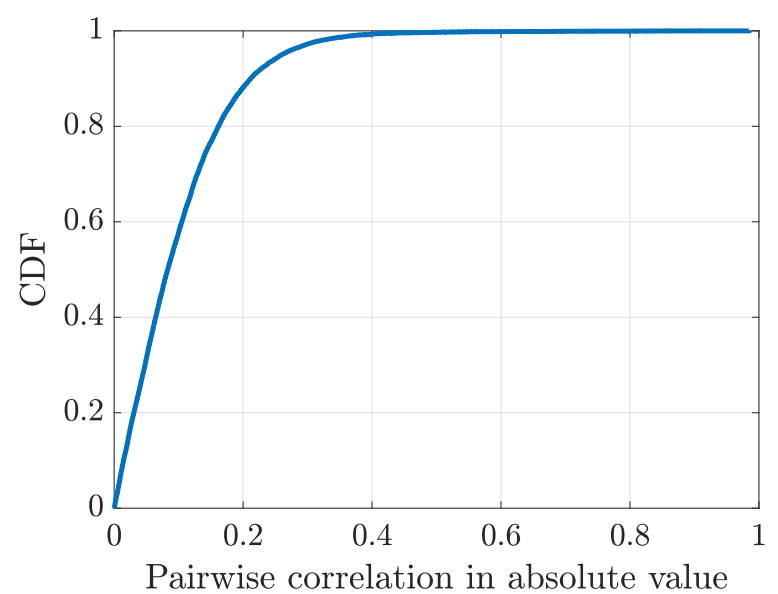

(d) Residual cross-sectional dependence

Finally, given the large changes experienced globally over the last decades, we check for the possibility of structural breaks in the coefficients of the GVAR, by employing several statistics which test the null hypothesis of parameter stability of each equation for each country model. ${ }^{13}$ Table 3 reports the rejection rates of these tests, which measure the share of equations in which the null of parameter stability is rejected for different levels

\footnotetext{
${ }^{13}$ We consider the following traditional tests: the Ploberger and Krämer (1992) maximal OLS cumulative sum statistic, denoted by $P K_{\text {sup }}$ and its mean square variant $P K_{m s q}$, and the heteroskedasticityrobust versions of the Nyblom (1989) test, denoted by $R$, of the Quandt (1960) likelihood ratio statistic $(Q L R)$, of the Andrews and Ploberger (1994) mean Wald statistic $(M W)$ and the exponential average $(A P W)$ version. The critical values of these tests, computed under the null of parameter stability, are calculated by bootstrapping the GVAR model.
} 
of significance. Results from all tests coincide in that the null hypothesis of parameter stability is not rejected for the vast majority of equations. For instance, by looking at the $5 \%$ significance level, the null is rejected at most in $13 \%$ of the equations according to the Nyblom $(R)$ test, while the corresponding figures for the rest of statistics are even lower. These results are in line with Dées et al. (2007), which highlight that the inclusion of foreign variables in country-specific models allows for accommodating situations of cobreaking, that occur when country-specific equations are subject to breaks roughly around the same time in different economies. ${ }^{14}$ By accommodating for co-breaking, the structure of the GVAR is more robust to the possibility of structural breaks than alternative approaches and thus helps in alleviating the problem of parameter instability.

Table 3: Rejection rates of the null of parameter constancy across country-specific models

\begin{tabular}{lcccccc}
\hline & \multicolumn{5}{c}{ Test statistics } \\
\cline { 2 - 7 } Significance level & $P K_{\text {sup }}$ & $P K_{m s q}$ & $R$ & $Q L R$ & $M W$ & $A P W$ \\
\hline \multirow{2}{*}{$10 \%$} & 0.18 & 0.07 & 0.23 & 0.18 & 0.20 & 0.19 \\
$5 \%$ & 0.10 & 0.05 & 0.13 & 0.07 & 0.10 & 0.07 \\
$1 \%$ & 0.02 & 0.00 & 0.08 & 0.02 & 0.01 & 0.02 \\
\hline
\end{tabular}

Notes: share of equations in which the null of parameter stability is rejected for different significance levels. $P K_{\text {sup }}$ and $P K_{m s q}$ denote the Ploberger and Krämer (1992) maximal OLS cumulative sum statistic and its mean square variant; $R$ denotes the Nyblom (1989) test; $Q L R$ denotes the Quandt (1960) likelihood ratio statistic; $M W$ and $A P W$ denote the Andrews and Ploberger (1994) mean Wald statistic and its exponential average variant. The critical values of these tests, computed under the null of parameter stability, are calculated by bootstrapping the GVAR model.

\section{Results}

\subsection{US Monetary Policy and the Global Financial Cycle}

We first present results of an expansionary US monetary policy shock which reduces the US short-term interest rate by 25 basis points on impact. ${ }^{15}$ Figure 2 reports the median

\footnotetext{
${ }^{14}$ Further details on the concept of co-breaking can be found in the seminal work by Hendry (1996), as well as in Hendry and Mizon (1998).

${ }^{15}$ Being the model linear in the shock, a contractionary monetary policy shock which increases the US short-term interest rate by the same amount would lead to the same responses but with switched signs.
} 
responses for the rest of the world, joint with the 16th and 84th percentiles, as well as the median responses for the United States. On the domestic side, the expansionary shock improves financial conditions by rising equity prices and gross capital inflows, and stimulates macroeconomic activity and prices. More importantly though, the US monetary easing triggers a risk-on environment featured by surges of capital inflows in the rest of the world and increases of international equity prices. ${ }^{16}$ As a consequence, global GDP growth and inflation increase, thereby putting upward pressure to oil prices. Global interest rates, which do not react on impact, steadily increase to tame overheating pressures and reach a peak of 20 basis points after three quarters. Importantly, the shock induces notable macro-financial spillovers that are generally similar in size to the domestic effects. These findings are suggestive that the US monetary easing contributes to the emergence of a Global Financial Cycle which boosts macroeconomic activity worldwide.

Figure 2: Domestic and global effects of a drop in US policy rate
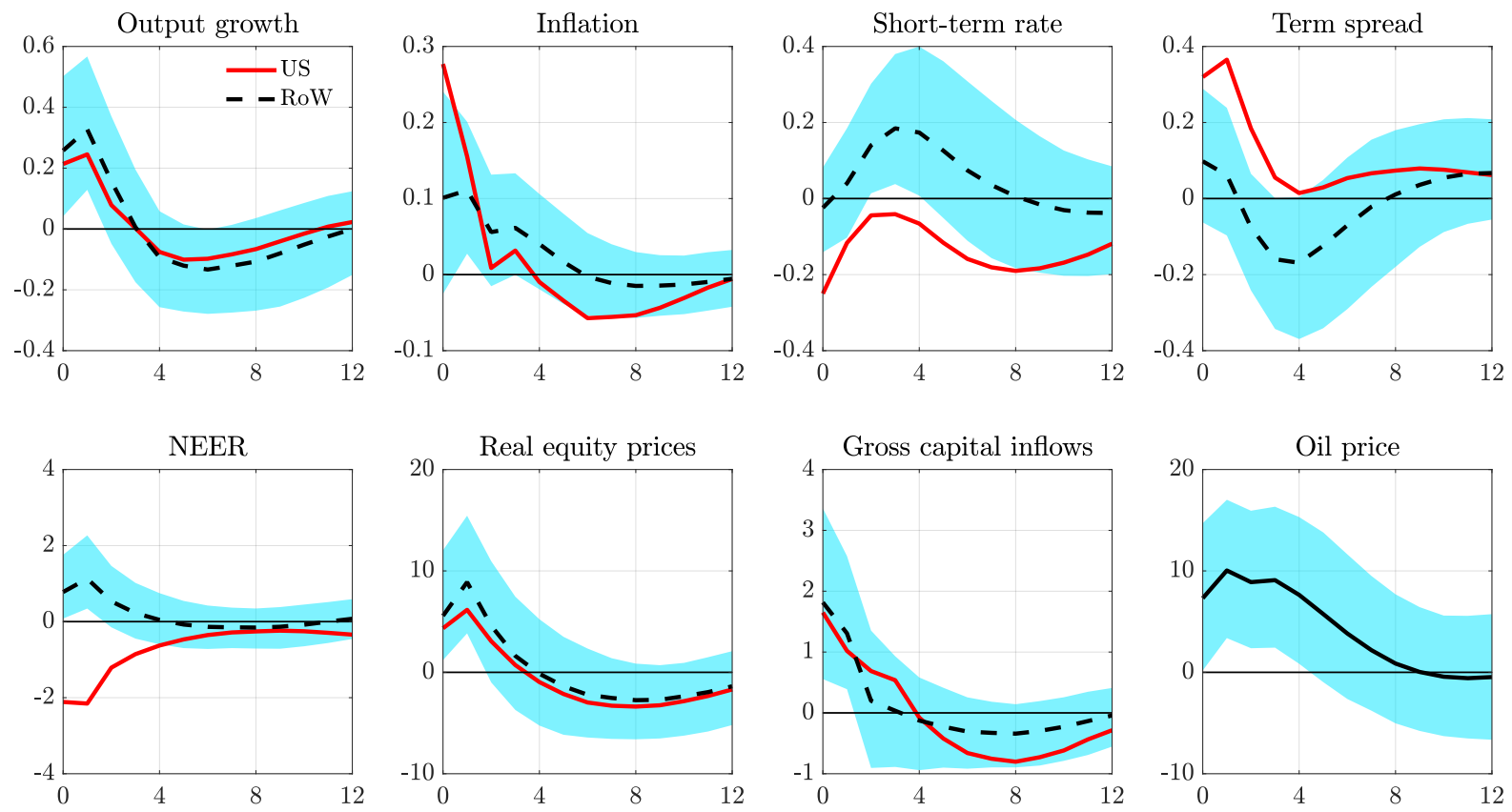

Notes: median responses for the rest of the world in dashed black, joint with 16th and 84th percentiles, and median responses for the US in solid red, to an expansionary US monetary policy shock which decreases on impact the US short-term rate by 25 basis points. $x$ and $y$ axes measure quarters and percentage points, respectively.

\footnotetext{
${ }^{16}$ In this respect, Forbes and Warnock (2012) find that lower levels of global risk lead to worldwide increases in gross capital inflows.
} 
The presented evidence gets further support when focussing on the international transmission of an unexpected flattening of the US yield curve. Again, the monetary easing boosts international capital flows and equity prices, thereby increasing global growth, inflation, as well as oil prices. Short-term interest rates gradually increase to dissipate the overheat in the global economy, reaching about 50 basis points after one year. This evidence further corroborates the idea that expansionary US monetary policy surprises significantly boost not only macroeconomic but also financial activity worldwide, regardless of whether the monetary easing is achieved by a conventional drop in the policy rate or by a compression of the yield spread.

Figure 3: Domestic and global effects of a compression in US term spread
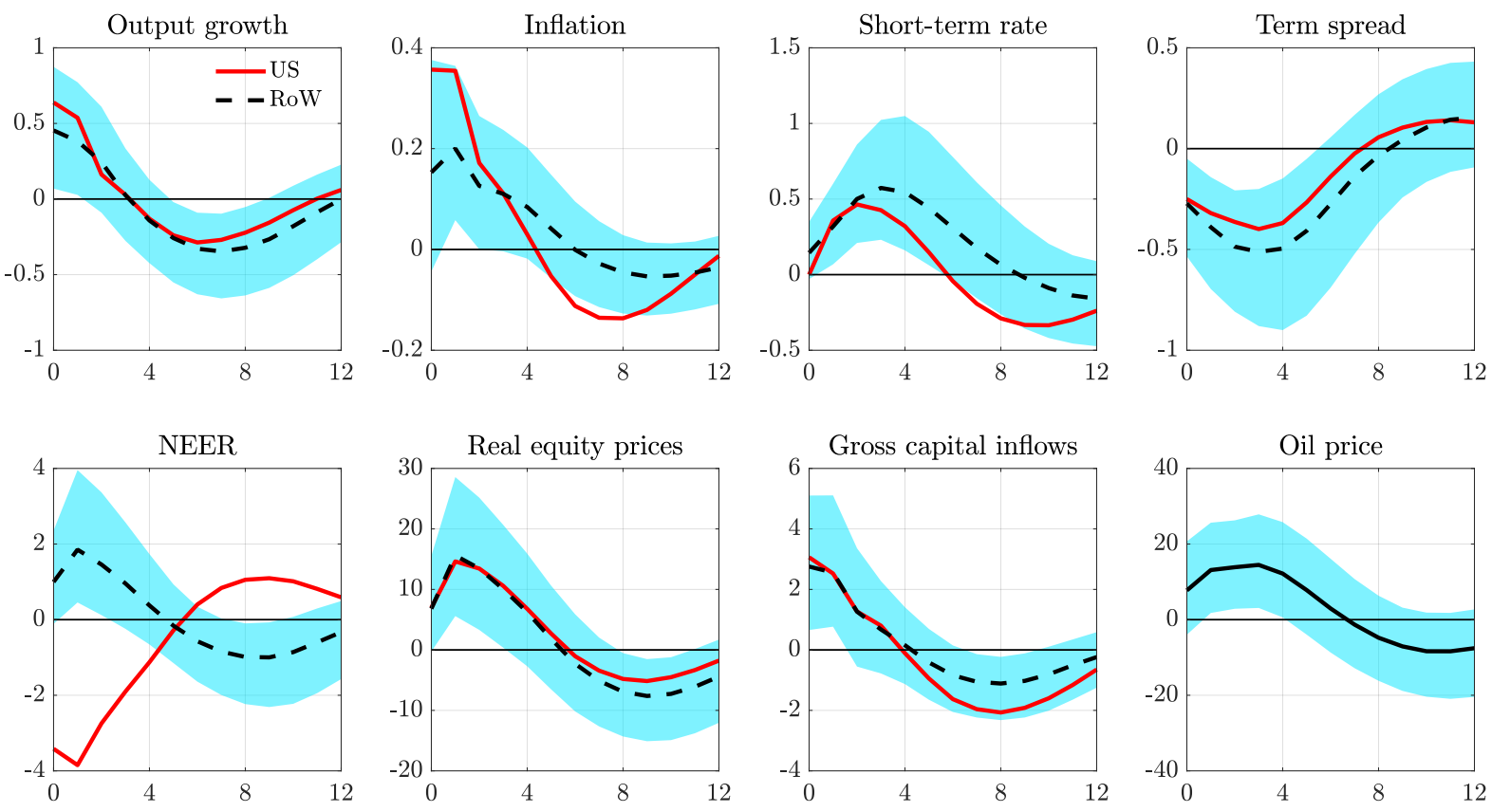

Notes: median responses for the rest of the world in dashed black, joint with 16th and 84th percentiles, and median responses for the US in solid red, to an expansionary US monetary policy shock which decreases on impact the US term spread by 25 basis points. $x$ and $y$ axes measure quarters and percentage points, respectively.

As robustness, we experiment two alternative exercises in which we explore the effects of US monetary policy by accounting for an effective lower bound in the policy rate. First, we simulate an unexpected drop in the US shadow interest rate of Wu and Xia (2016), by imposing the same sign restrictions employed for the conventional monetary policy shock as reported in Table 2. Second, we simulate an unexpected compression of the US yield 
spread while at the same time imposing that the US short-term interest rate cannot move over three years from the shock. The latter exercise is practically implemented by zeroing out the structural US short-term interest rate equation over three years, in the vein of Baumeister and Benati (2013). As reported in Figure 11 in Appendix, these alternative simulations yield qualitatively unchanged results.

\subsection{Spillovers and Exchange Rate Regimes}

In this section we look at previous results with more detail regarding how effects vary across countries and whether they differ according to exchange rate regimes. By focussing first on the whole distribution of country-specific spillovers, we provide further evidence on the role of US monetary policy as a driver of global macroeconomic and financial cycles. Figure 4 plots the median peak effects (or trough in case of negative responses) of country-level responses to output growth, equity prices and gross capital inflows, joint with the 16th and 84th percentiles. Easing US monetary policy leads to economically and statistically significant increases in capital inflows, equity prices and output growth for the vast majority of countries. This result holds regardless of whether the expansionary monetary impulse is implemented via a drop in the policy rate or a flattening of the yield curve.

Macro-financial spillovers are significant even in economies with floating exchange rate regimes like the euro area or UK. Nonetheless, a flexible exchange rate could still provide a partial insulation to the foreign shock, so we formally test whether this is the case. Specifically, we split our sample in two groups following the IMF's de facto classification of exchange rate arrangements: one group consists of those countries whose currency is independently floating (Floaters), while the other group includes the rest of countries (Non-floaters). ${ }^{17}$ Then, we compute group-specific responses to the US monetary policy shock, as well as their discrepancy. We finally test whether the discrepancy of responses is statistically different from zero to conclude whether having a floating exchange rate makes a difference.

\footnotetext{
${ }^{17}$ Independently floaters in our sample are Australia, Brazil, Canada, Chile, euro area, Japan, Korea, Mexico, New Zealand, Norway, Philippines, South Africa, Sweden, Switzerland, Turkey, and United Kingdom.
} 
Figure 4: Country-level spillover effects to expansionary US monetary policy shocks
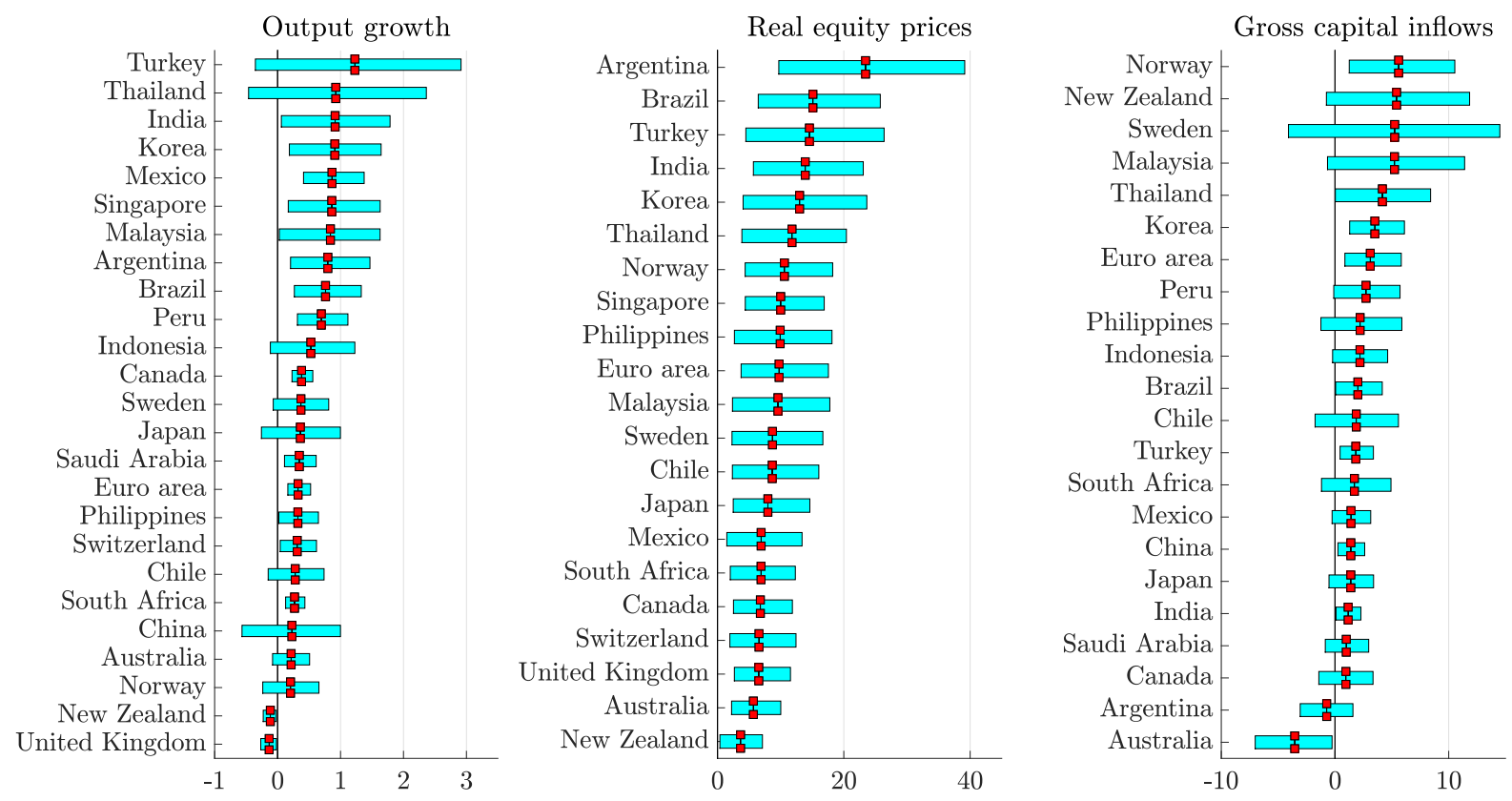

(a) Drop of US policy rate
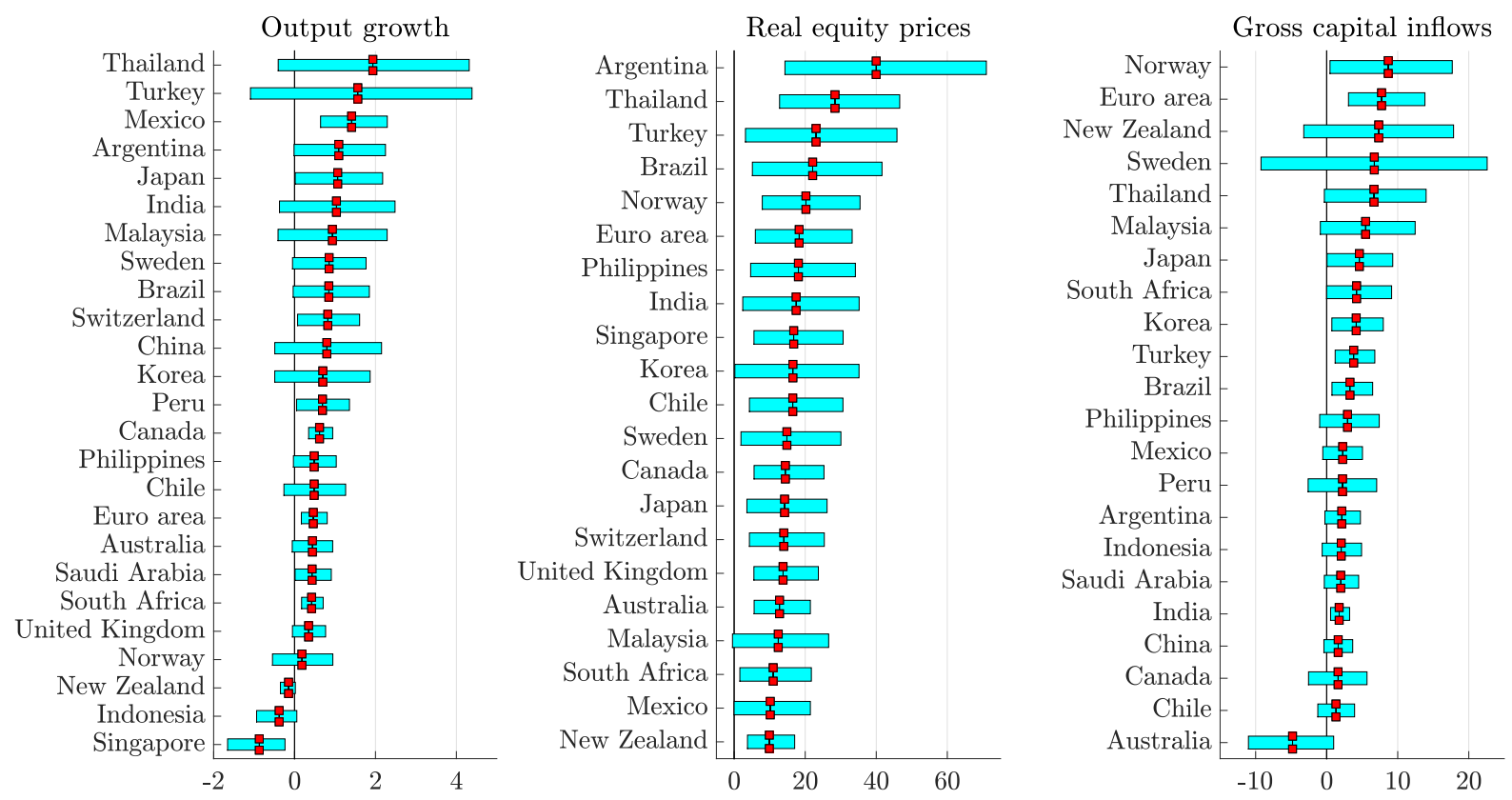

(b) Compression of US term spread

Notes: peak effects (or trough, if negative response), medians, 16th, and 84th percentiles, to an expansionary US monetary policy shock which either decreases on impact the US short-term rate by 25 basis points (panel a), or which decreases on impact the US term spread by 25 basis points (panel b). Notice that we exclude gross capital inflows into Singapore, Switzerland, and United Kingdom due to high values. $x$ axis measures percentage points. 
Figure 5: Exchange rate and spillovers to expansionary US monetary policy shocks
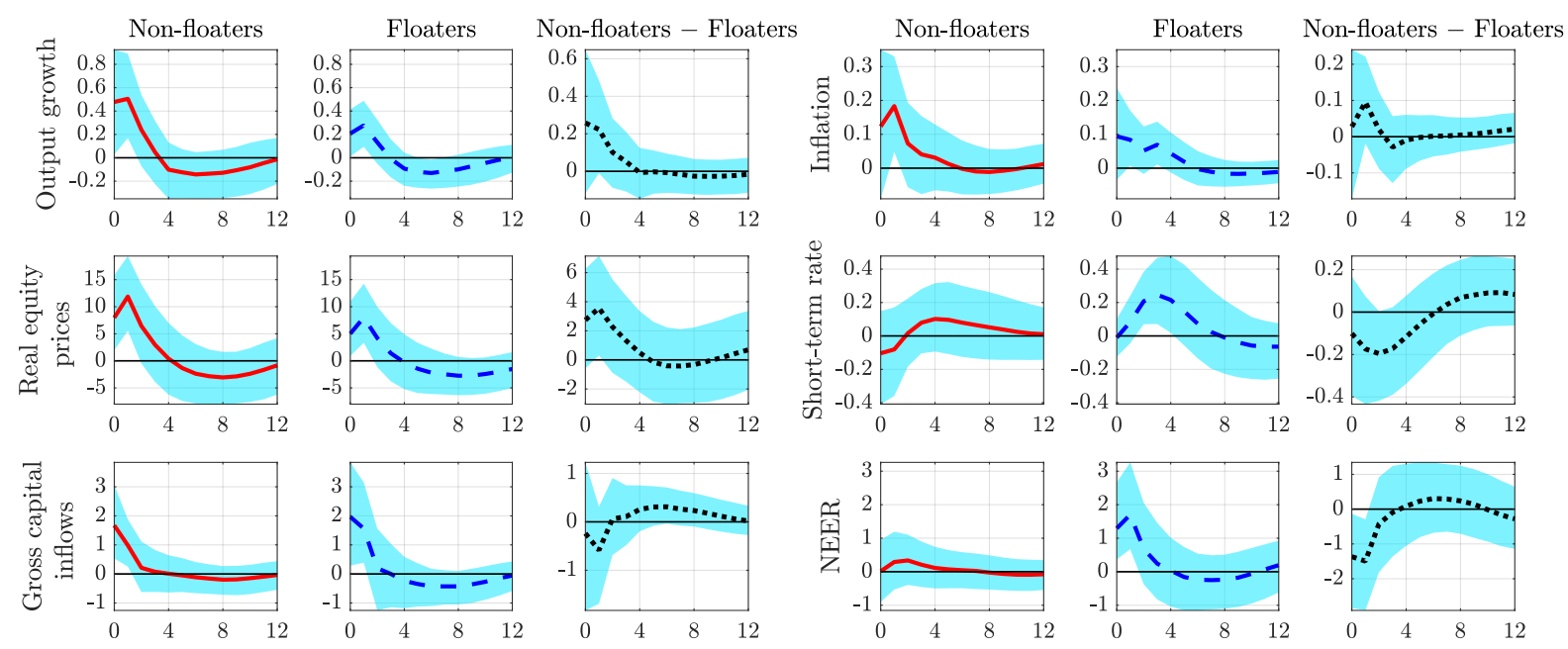

(a) Drop of US policy rate
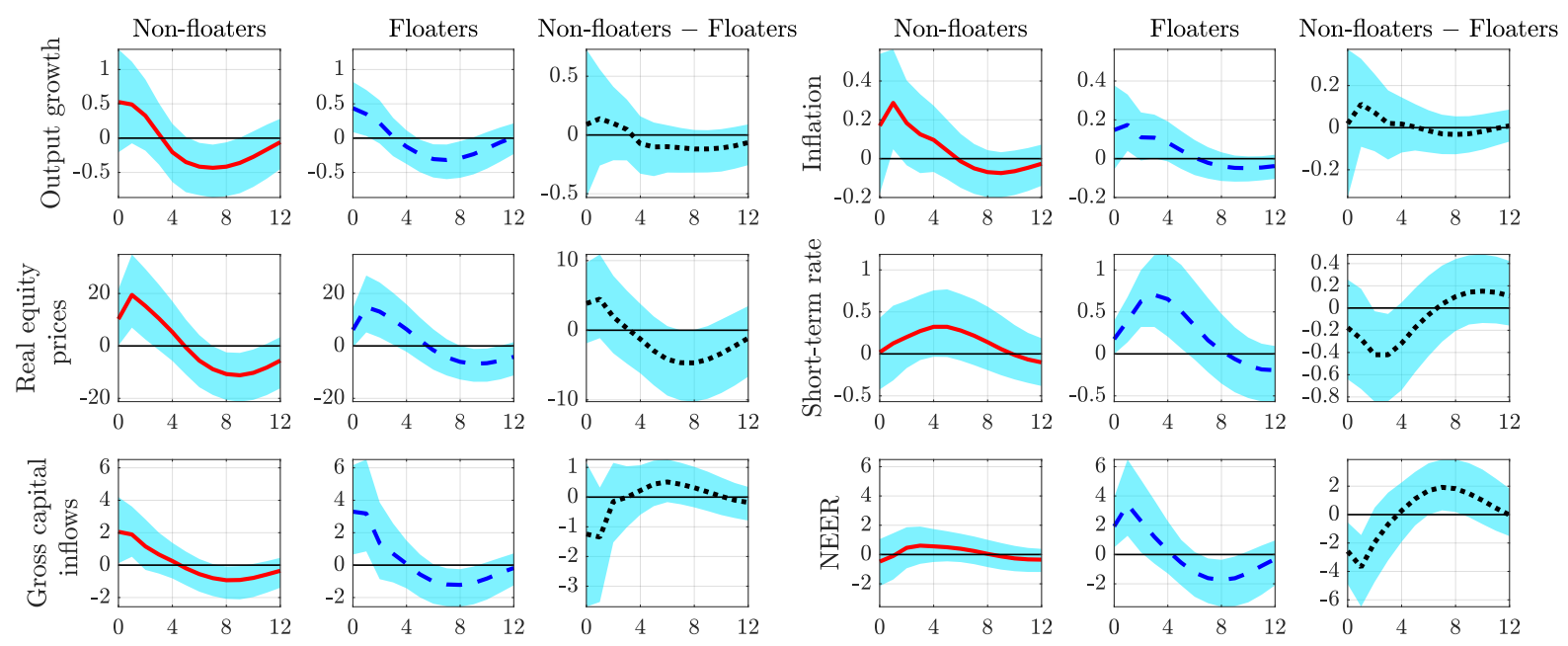

(b) Compression of US term spread

Notes: median responses joint with 16th and 84th percentiles for the non-floaters (solid red), floaters (dashed blue), and the discrepancy non-floaters minus floaters (dotted black), to an expansionary US monetary policy shock which either decreases on impact the US short-term rate by 25 basis points (panel a), or which decreases on impact the US term spread by 25 basis points (panel b). $x$ and $y$ axes measure quarters and percentage points, respectively.

We report results in Figure 5, which shows median responses, joint with the 16th and 84th percentiles, for the group of Non-floaters, Floaters, and for the discrepancy between the two group-specific responses. Macro-financial spillovers are generally sizable and statistically significant both for non-floaters and for countries whose currency is independently floating. Floaters tend to feature relatively smaller spillovers, for instance in 
output growth and equity prices, which is in line with the Trilemma predictions. However, the differential between-group effects are generally not statistically different from zero. The unique exception is the behavior of the exchange rate, for which we observe a strong and sudden appreciation in floating economies vis-ï£j-vis non-floaters. This result confirms previous country-level evidence that a floating exchange rate cannot offer a full insulation to US monetary policy shocks and, if anything, having a flexible exchange rate provides just a limited insulation to foreign shocks. ${ }^{18}$

\subsection{Disentangling the Network Effects of International Spillovers}

We have shown that US monetary policy shocks generate strong macroeconomic and financial spillovers in most countries. In this section we uncover to what extent these effects get reinforced by the complex network of interactions across countries. To this end, we compare the estimated effects with those arising from a similar US monetary policy surprise estimated from a model which does not account for network effects. The alternative model simplifies in two directions. The first simplification is that the US economy is exogenous to developments in the rest of the world, so that any potential spillback effect is shut down. This assumption amounts to drop the set of country-specific foreign variables from the US model in equation (1), which boils down to

$$
Y_{U S, t}=a_{U S}+b_{U S} t+\sum_{j=1}^{p_{U S}} A_{U S, j} Y_{U S, t-j}+\sum_{j=0}^{q_{U S}} C_{U S, j} X_{t-j}+u_{U S, t}
$$

Still, US variables depend on developments in oil prices, $X_{t}$. However, while oil prices in the baseline model are endogenous to global growth and inflation according to (3), here we allow them to depend just on US developments, by accordingly setting the feedback variables, $\tilde{Y}_{t}$, equal to its US equivalents.

The second simplification with respect to the baseline specification is that all bilateral interactions among all countries in the rest of the world are precluded, so that higher order effects are ruled out. By setting to zero the trade-based weights of all countries excluding the US, whose weight is equal to one, equation (2) states that the foreign variables of each

\footnotetext{
${ }^{18}$ We further refine the analysis by comparing only those countries that feature high levels of capital controls according to the classification in Fernï£indez et al. (2015). Figures 12 and 13 in Appendix show that, once controlling for capital controls, qualitative results remain unchanged.
} 
given economy $i$ are given by the US variables, $Y_{i t}^{*}=Y_{U S, t}$. Hence each country-specific model specified in (1) boils down to,

$$
Y_{i t}=a_{i}+b_{i} t+\sum_{j=1}^{p_{i}} A_{i j} Y_{i, t-j}+\sum_{j=0}^{q_{i}} B_{i j} Y_{U S, t-j}+\sum_{j=0}^{q_{i}} C_{i j} X_{t-j}+u_{i t} \quad \text { for } \quad i \neq U S
$$

In this way, each country in the rest of the world depends just on developments in the US and in the price of oil, the latter being dependent on US variables only. Apart from these two simplifications, this alternative model keeps the specification of the baseline in terms of sets of domestic and foreign variables, lag structure, and identification strategy of the US monetary policy shocks. Figure 6 compares the structure of the benchmark GVAR with the one of this alternative specification, where each node indicates a country-specific model and each directional edge measures the relative importance of a country for a given economy. The benchmark specification in panel (a) allows the US monetary policy shock to propagate among receiver countries, as well as for spillback effects from countries in the rest of the world to the US economy itself. Conversely, the alternative specification in panel (b) let the US monetary impulse to affect all countries altogether, but precludes the shock to propagate among receiving countries, as well as any second-round effect from the rest of the world to the US economy.

Figure 6: The GVAR structure with and without network effects

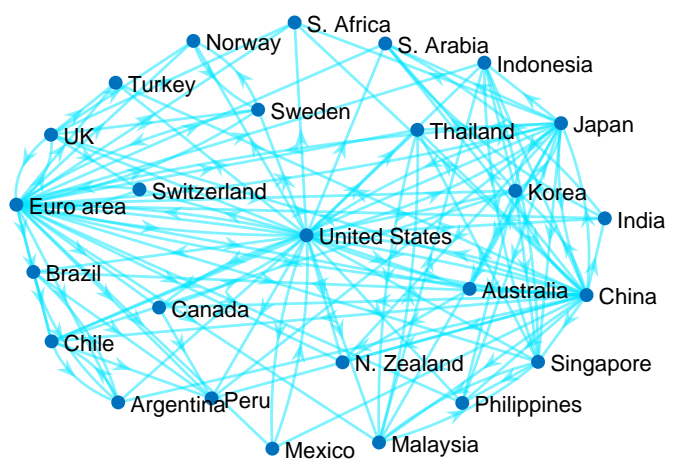

(a) Benchmark network

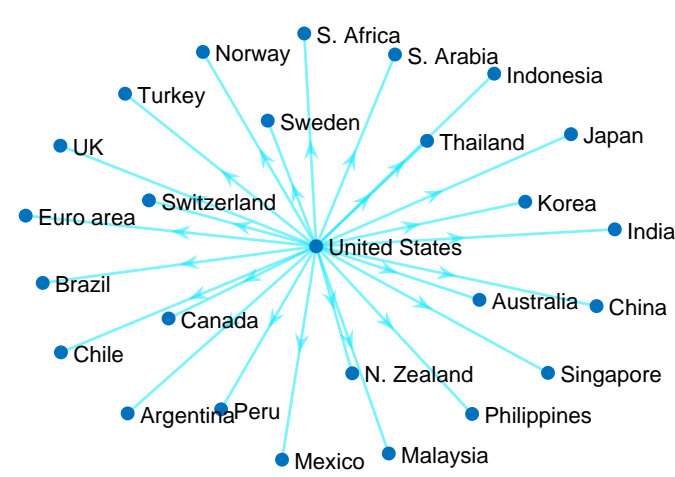

(b) No network effects

Notes: directional edge from country $j$ to country $i$ reflects the relative importance of country $j$ for country $i$, as measured by the weight $w_{i j}$. Edges in light blue if $w_{i j}>5 \%$, not displayed otherwise. For panel (a), weights are computed using average bilateral trade flows over the years 1994-2016. For panel (b), weights $w_{i j}$ for $j \neq U S$ are set to zero, while weights $w_{i, U S}$ are set to unity. 
Figure 7 compares the domestic and spillover effects, averaged over the first year from the shock, to US monetary policy surprises implied by the baseline model and the alternative version that precludes network effects, while Figure 14 in Appendix reports the full set of responses. Network effects substantially amplify macro-financial spillovers of expansionary US monetary policy shocks, regardless of whether the easing is undertaken via conventional or unconventional measures. A 25 basis points drop in US policy rate implies a more than doubled increase in global growth when network effects are taken into account $(0.08 \%$ without network effects versus $0.19 \%$ in the baseline), and similarly so with a 25 basis points compression in the US yield spread $(0.12 \%$ and $0.28 \%$ without and with network effects, respectively). In the same vein, network effects lead to roughly doubled increases in global equity prices and capital inflows.

Figure 7: The role of the network for domestic and spillover effects
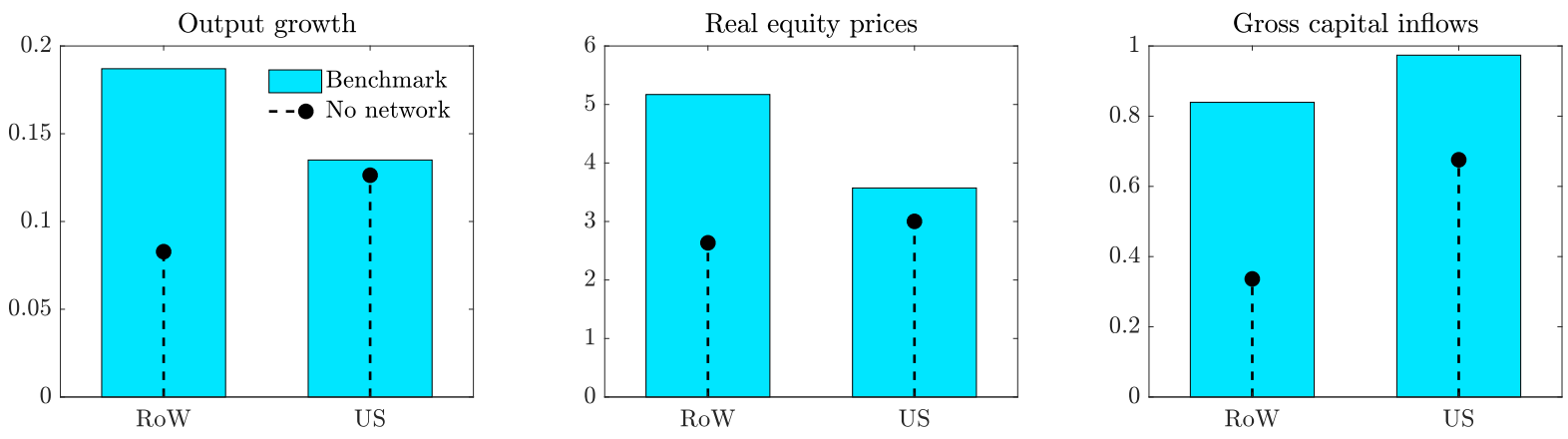

(a) Drop of US policy rate
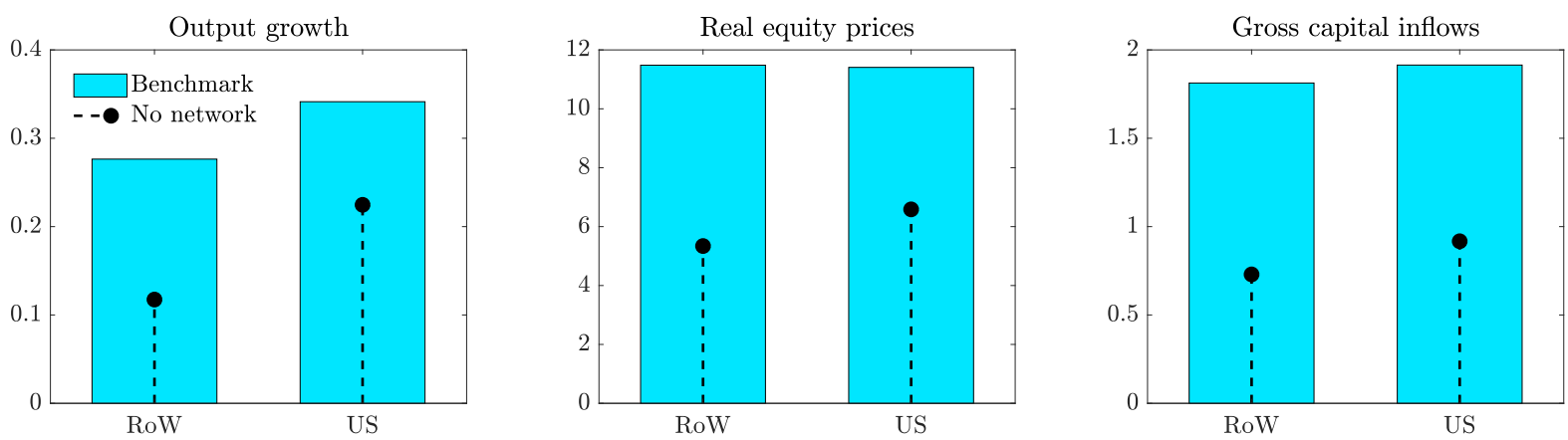

(b) Compression of US term spread

Notes: average one-year effects for the rest of the world (RoW) and United States to an expansionary US monetary policy shock which either decreases on impact the US short-term rate by 25 basis points (panel a), or which decreases on impact the US term spread by 25 basis points (panel b) for the baseline model (Benchmark) and for an alternative model which precludes network effects (No network). y axes measure percentage points. 
Interestingly, network effects also amplify the domestic effects of US monetary policy shocks, and particularly so when considering compressions in the US yield spread. The boost in domestic growth induced by the monetary easing is about $0.22 \%$ without network effects, and it averages $0.34 \%$ when network effects are in place. The corresponding figures for US equity prices are $6.6 \%$ and $11.4 \%$, respectively without and with network effects. These results confirm the view that international effects of US monetary policy sensibly spill back onto the evolution of the US economy itself.

Figure 8: The role of the network for spillover effects, country-level evidence
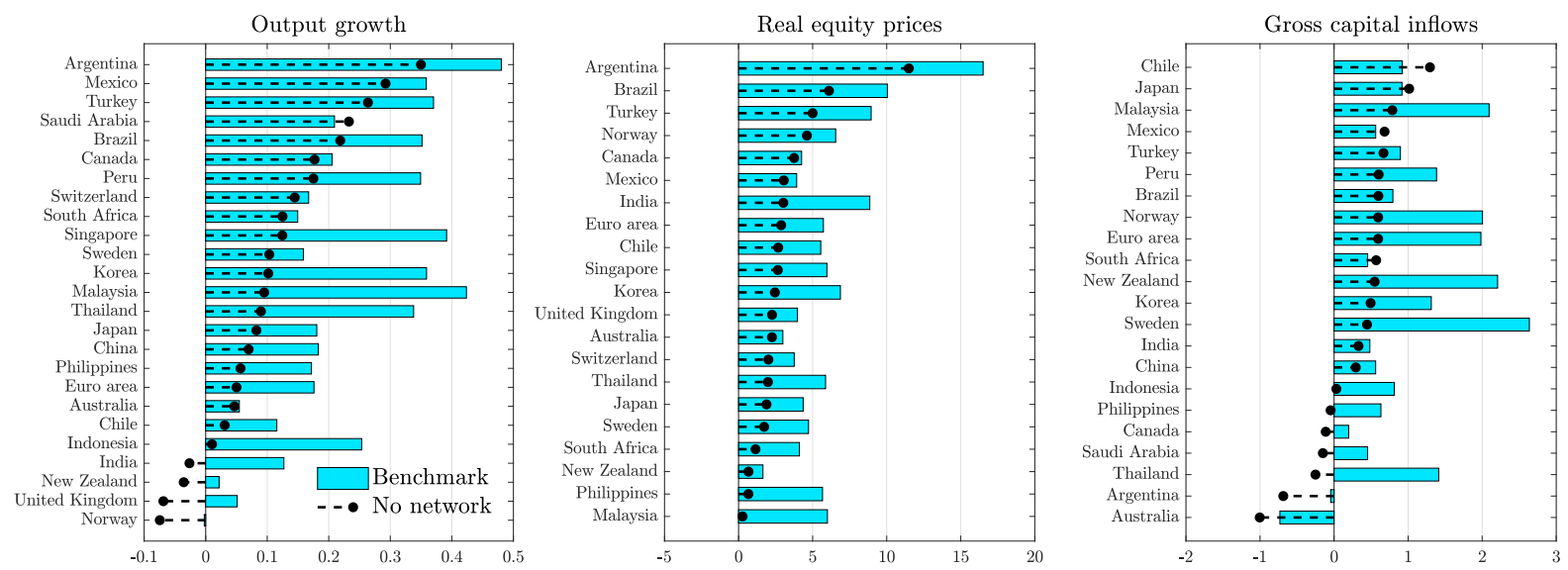

(a) Drop of US policy rate
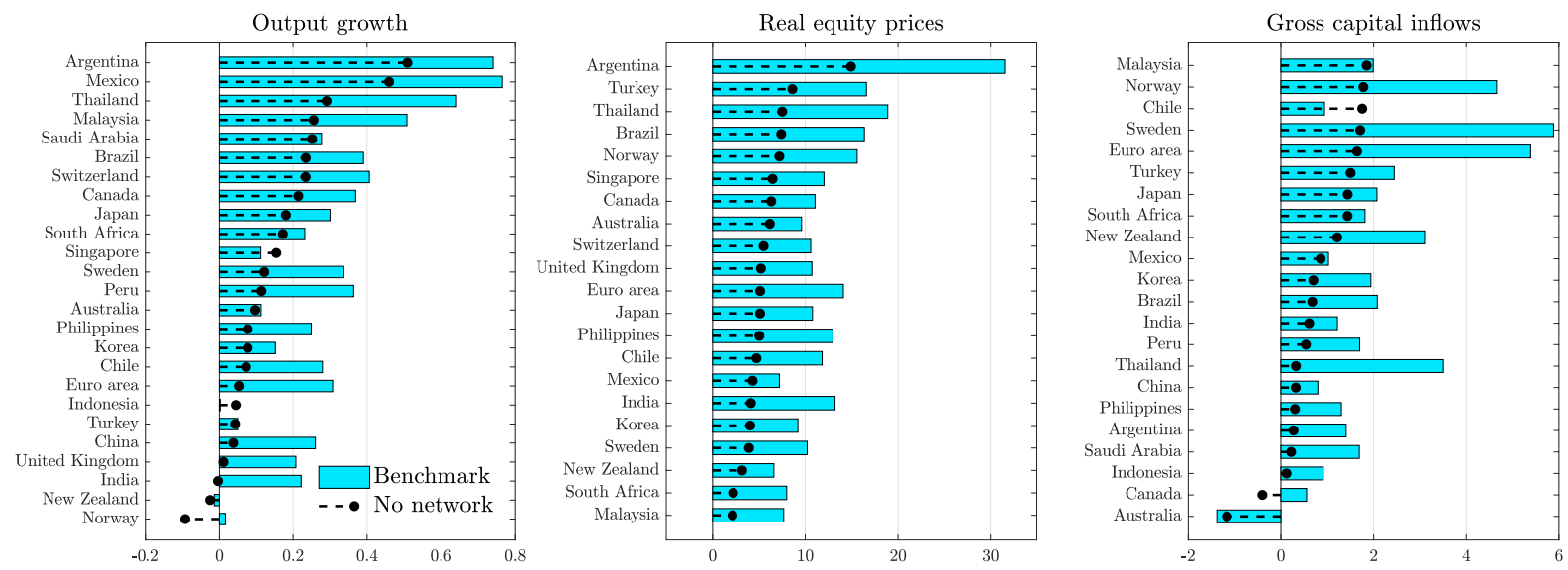

(b) Compression of US term spread

Notes: average 1-year effects to an expansionary US monetary policy shock which either decreases on impact the US shortterm rate by 25 basis points (panel a), or which decreases on impact the US term spread by 25 basis points (panel b) for the baseline model (Benchmark) and for an alternative model which precludes network effects (No network). y axes measure percentage points. 
Overall, we find that the role of US monetary policy in driving not only financial but also macroeconomic activity on a global scale gets amplified by the complex network of cross-country interactions. The evidence is even more striking in Figure 8, which reports the full cross-country distribution of spillovers. Network effects amplify macrofinancial spillovers across the board, with substantial heterogeneity across countries. In particular, economies which are mostly dependent on the US economy such as Canada and Mexico expectedly feature smaller amplification effects from the network, while the opposite holds for economies with a more diversified set of trading partners, such as the euro area. These results are consistent with Georgiadis (2017), which shows that spillovers of US monetary policy shocks estimated from models that do not factor in network effects (such as bilateral VARs) are systematically smaller than those obtained from a GVAR model, and discrepancies are more pronounced for economies for which the US accounts for a smaller share of their overall trade and financial integration.

We investigate US monetary policy spillovers further by studying whether changes occurred in the network structure over the last decades had an effect in shaping the size of global spillovers. Figure 9 plots the structure of the network as it evolves over time. It is interesting to observe that while in the pre-2000's period the United States were a particularly relevant trade partner for several economies in the Western Hemisphere (Brazil, Canada, Mexico, and Peru) and in Asia (Japan, Korea, and Philippines), their relative role has been gradually falling over time, first by losing trade shares in Korea and Philippines over the years 2000-2007, then by experiencing a drop in trade shares relative to Brazil, Japan, and Peru after the Great Recession. Overall, the rest of the world has on average experienced a steady decline in the degree of bilateral integration with the United States. While the US were accounting for about $25 \%$ of trade before of the 2000's, this figure has declined to $21 \%$ in the early 2000 's and reached about $17 \%$ in the most recent period. This pattern, which is also present in other advanced economies such as the euro area and Japan, is attributable to the steady rise of emerging economies (and particularly by China), whose trade share has doubled from $18 \%$ to $36 \%$ in roughly two decades. ${ }^{19}$ Hence specularly, the rest of the world has on average observed an increase

\footnotetext{
${ }^{19}$ Following the classification of the IMF World Economic Outlook, the emerging economies in our
} 
in the degree of global integration vis-ï j-vis the rest of the countries excluding the US, ranging from a trade exposure of $75 \%$ in the pre-2000's up to $83 \%$ over the most recent years.

Figure 9: Evolution of the network structure over time

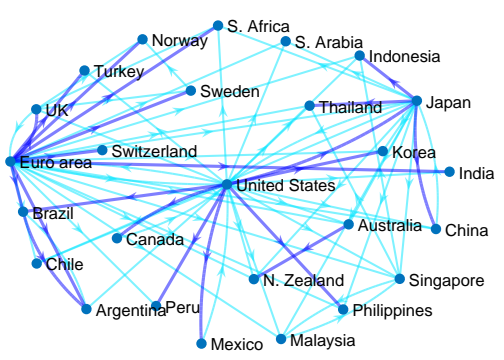

(a) Pre-2000's network

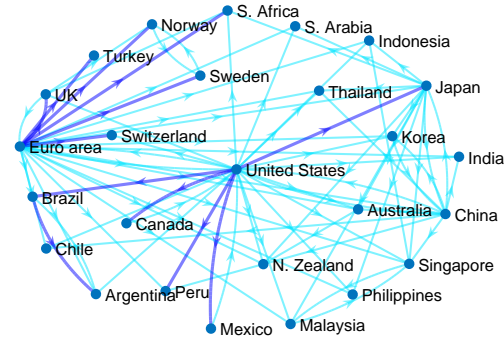

(b) Early 2000's network

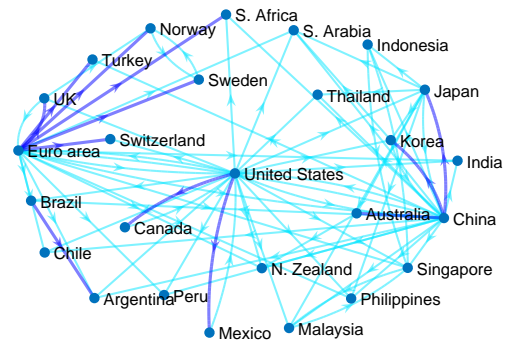

(c) Post-crisis network

Notes: directional edge from country $j$ to country $i$ reflects the relative importance of country $j$ for country $i$, as measured by the weight $w_{i j}$. Edges in dark blue if $w_{i j}>25 \%$, in light blue if $w_{i j} \in(10 \%, 25 \%)$, and not displayed if $w_{i j}<10 \%$. Weights are computed using average bilateral trade flows over the years 1994-1999 (Pre-2000's network), over the period 2000-2007 (Early 2000's network), and over the period 2008-2016 (Post-crisis network).

To study the implications of these shifts in the cross-country network, we explore alternative versions of the GVAR by sequentially varying the trade-based weights matrix employed to construct country-specific foreign variables in equation (2). Namely, we consider three models that exploit data on average bilateral trade flows over the years 1994-1999 (Pre-2000's network), over 2000-2007 (Early 2000's network), and over 20082016 (Post-crisis network). Apart from the cross-country weights matrix, all models are estimated over the same sample and share the specifications of the baseline model, so that we can assess the role of the network structure as it evolved over time.

Figure 10 reports the spillover effects on the global economy (excluding the US), to the two types of expansionary US monetary policy surprises. Two results are worth pointing out. First, network effects tend to amplify the spillover effects of US monetary policy, regardless the choice of the network structure and whether the easing is undertaken via conventional or unconventional measures. In fact, the model without cross-country network implies systematically smaller effects than those obtained by the alternative versions sample are Argentina, Brazil, Chile, China, India, Indonesia, Malaysia, Mexico, Peru, Philippines, Saudi Arabia, South Africa, Thailand, and Turkey. 
that account for both bilateral interactions among receiver countries and spillback effects to the US economy. Second, the amplification of the network tends to increase as the network evolves over time, and especially so in the case of a traditional policy rate drop. With the pre-2000's network structure in place, a 25 basis points drop of the US policy rate boosts global growth and equity prices by $0.15 \%$ and $3.8 \%$ respectively. The same figures are higher and average nearly $0.20 \%$ and $5.8 \%$ with the most recent post-Great Recession network, and a similar picture arises regarding the effect on global capital flows. Overall, these findings suggest that the evolution of the network is an important driver of the increasing role of US monetary policy in shaping the Global Financial Cycle.

Figure 10: Spillover effects and the evolving role of the network
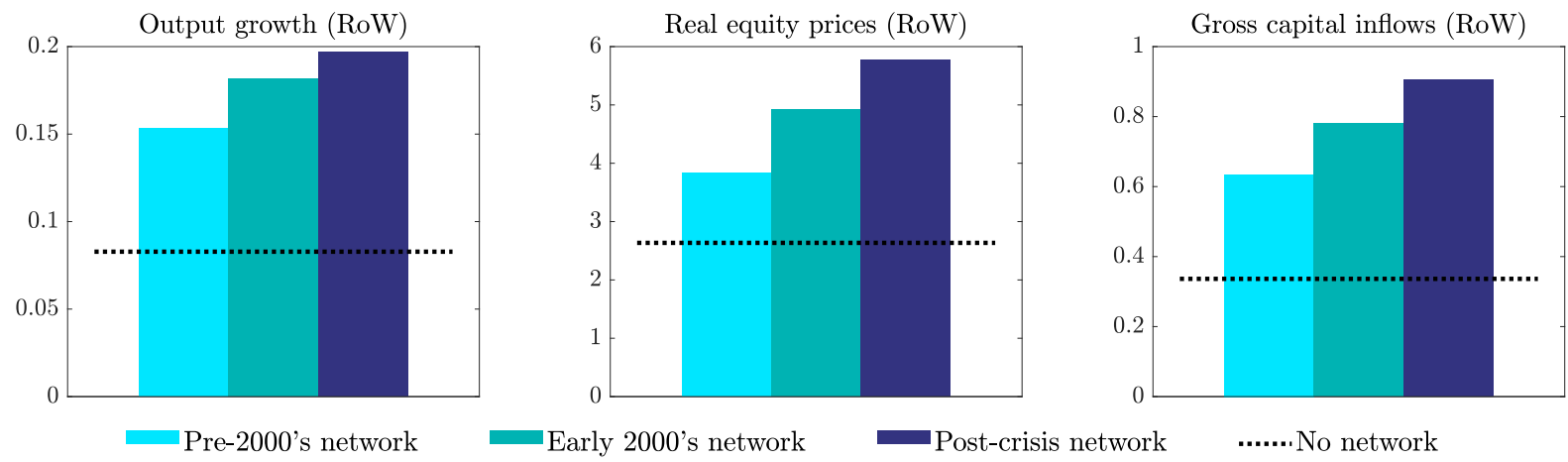

Early 2000's network Post-crisis network

....... No network

(a) Drop of US policy rate
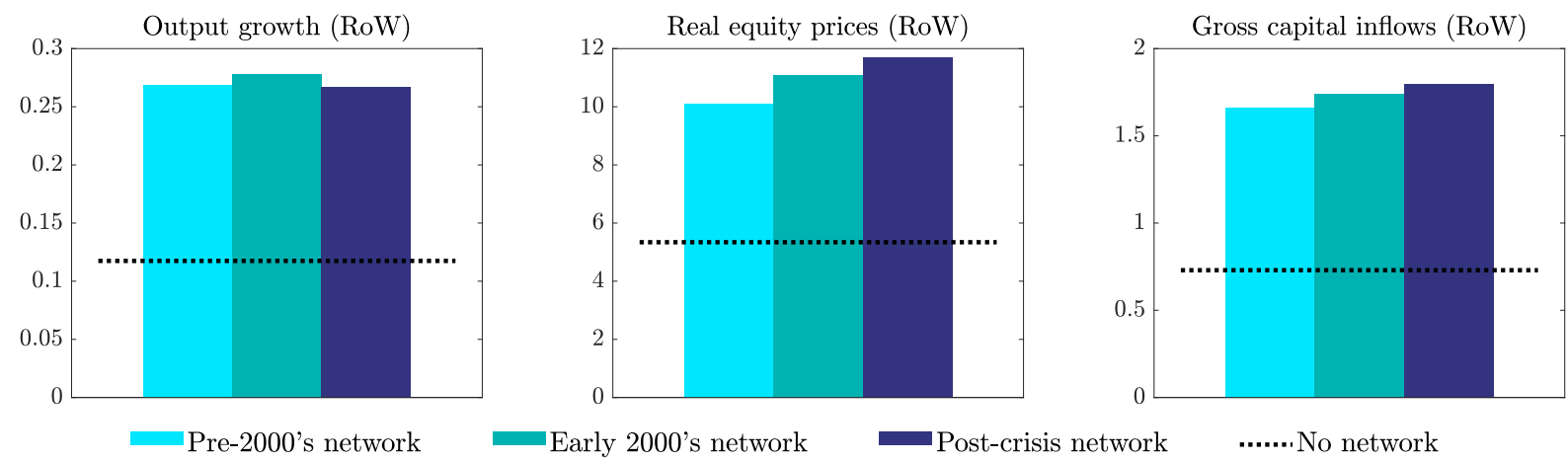

(b) Compression of US term spread

Notes: average one-year effects for the rest of the world (RoW) to an expansionary US monetary policy shock which either decreases on impact the US short-term rate by 25 basis points (panel a), or which decreases on impact the US term spread by 25 basis points (panel b) for the model which exploits data on average bilateral trade flows over the years 1994-1999 (Pre-2000's network), over the period 2000-2007 (Early 2000's network), over the period 2008-2016 (Post-crisis network), and for the model which precludes network effects (No network). $y$ axes measure percentage points. 


\section{Conclusions}

The recent view of the Global Financial Cycle has emphasized the existence of powerful financial spillovers of US monetary policy to the rest of the world, even in countries with floating exchange rate regimes. Since US monetary policy endogenously responds to the global consequences of its own measures, its role in driving the Global Financial Cycle could get potentially amplified by spillback effects and more generally by the complex network of cross-country interactions that arise in an highly integrated global economy. We investigate this possibility by means of an estimated GVAR, a multi-country empirical framework which models the global economy as a network of interdependent countries. We identify (un)conventional US monetary policy shocks using theory-based sign restrictions on selected responses of US variables, while at the same time leaving unrestricted the responses of all variables in the rest of countries so to allow for an agnostic identification strategy about the size and sign of international spillovers.

We show that unexpected expansionary US monetary policy surprises contribute to the emergence of a Global Financial Cycle that boosts macroeconomic activity worldwide, regardless of whether the monetary easing is achieved by a conventional drop in the policy rate or by a flattening of the yield curve. We also find that economies with floating exchange rate regimes are not fully insulated from US monetary policy shocks and, even though they appear to be relatively less affected by the shocks, the differences in responses across exchange rate regimes are not statistically significant. Importantly, the role of US monetary policy in driving these macro-financial spillovers gets even reinforced by the complex network of interactions across countries, to the extent that network effects roughly double the direct impacts of US monetary policy surprises on international equity prices, capital flows, and global growth. This amplification increases as countries get more globally integrated over time, suggesting that the evolving network is an important driver for the increasing role of US monetary policy in shaping the Global Financial Cycle. The channels through which countries interact are several, complex, and still not fully understood, and this question, which goes beyond the scope of our paper, is left for future research. Nonetheless our analysis highlights that accounting for such a network of 
cross-country interrelationships is a sensible dimension to consider in the current debate. 


\section{References}

Andrews, D. W., and W. Ploberger (1994). "Optimal tests when a nuisance parameter is present only under the alternative". Econometrica, 62, 1383-1414.

Arias, J., J. F. Rubio-Ramirez, and D. F. Waggoner (2018). "Inference Based on Structural Vector Autoregressions Identified with Sign and Zero Restrictions: Theory and Applications". Econometrica, 86, 685-720.

Baumeister, C., and L. Benati (2013). "Unconventional Monetary Policy and the Great Recession: Estimating the Macroeconomic Effects of a Spread Compression at the Zero Lower Bound". International Journal of Central Banking, 9, 165-212.

Burriel, P., and A. Galesi (2018). "Uncovering the heterogeneous effects of ECB unconventional monetary policies across euro area countries". European Economic Review, $101,210-229$.

Campbell, J. R., Evans, C. L., Fisher, J. D., Justiniano, A., Calomiris, C. W., and M. Woodford (2012). "Macroeconomic Effects of Federal Reserve Forward Guidance". Brookings Papers on Economic Activity, 1-80.

Carney, M. (2019). "Pull, Push, Pipes: Sustainable Capital Flows for a New World Order". Speech at the Institute of International Finance Spring Membership Meeting, Tokyo, 6 June 2019.

Chen, Q., Filardo, A., He, D., and F. Zhu (2016). "Financial crisis, US unconventional monetary policy and international spillovers". Journal of International Money and Finance, 67, 62-81.

Dedola, L., Rivolta, G. and L. Stracca (2017). "If the Fed sneezes, who catches a cold?". Journal of International Economics, 108, S23-S41.

Dées, S., F. di Mauro, M. H. Pesaran, and L. V. Smith (2007). "Exploring the international linkages of the euro area: a global VAR analysis". Journal of Applied Econometrics, 22, $1-38$. 
Ehrmann, M., and M. Fratzscher (2009). "Global Financial Transmission of Monetary Policy Shocks". Oxford Bulletin of Economics and Statistics, 71, 739-759.

Eickmeier, S., and T. Ng (2015). "How do US credit supply shocks propagate internationally? A GVAR approach". European Economic Review, 74, 128-145.

Feldkircher, M., and F. Huber (2016). "The international transmission of US shocks: evidence from Bayesian global vector autoregressions". European Economic Review, 81, $167-188$.

Fernï£jndez, A., Klein, M. W., Rebucci, A., Schindler, M., and M. Uribe (2015). "Capital control measures: A new dataset". NBER Working Paper No. 20970.

Fischer, S. (2014). "The Federal Reserve and the Global Economy". Per Jacobsson Foundation Lecture, Annual Meetings of the International Monetary Fund and the World Bank Group, Washington DC, 11 October 2014.

Forbes, K. J., and F. E. Warnock (2012). "Capital flow waves: Surges, stops, flight, and retrenchment". Journal of International Economics, 88, 235-251.

Forni, M., Hallin, M., Lippi, M., and L. Reichlin (2000). "The generalized dynamic-factor model: identification and estimation". Review of Economics and Statistics, 82, 540-554.

Georgiadis, G. (2015). "Examining asymmetries in the transmission of monetary policy in the euro area: Evidence from a mixed cross-section global VAR model". European Economic Review, 75, 195-215.

Georgiadis, G. (2016). "Determinants of global spillovers from US monetary policy". Journal of International Money and Finance, 67, 41-61.

Georgiadis, G. (2017). "To bi, or not to bi? Differences between spillover estimates from bilateral and multilateral multi-country models". Journal of International Economics, 107, 1-18. 
Gross, M., and C. Kok (2013). "Measuring contagion potential among sovereigns and banks using a mixed-cross-section GVAR". European Central Bank Working Paper Series, No. 1570.

Gükaynak, R. S., Sack, B. P., and E. T. Swanson (2005). "Do Actions Speak Louder than Words? The Response of Asset Prices to Monetary Policy Actions and Statements". International Journal of Central Banking, 1, 55-93.

Hendry, D. F. (1996). A theory of co-breaking. Mimeo, Nuffield College, University of Oxford.

Hendry, D. F., and G. E. Mizon (1998). "Exogeneity, causality, and co-breaking in economic policy analylsis of a small econometric model of money in the UK". Empirical Economics, 23, 267-294.

Iacoviello, M., and G. Navarro (2019). "Foreign effects of higher US interest rates". Journal of International Money and Finance, 95, 232-250.

Miranda-Agrippino, S., and H. Rey (2019). "US Monetary Policy and the Global Financial Cycle". mimeo, previously circulated as "World Asset Markets and the Global Financial Cycle". CEPR Discussion Paper No. 10936.

Mohaddes, K., and M. Raissi (2018). "Compilation, Revision and Updating of the Global VAR (GVAR) Database, 1979Q2-2016Q4". University of Cambridge: Department of Economics (mimeo).

Mundell, R. A. (1963). "Capital mobility and stabilization policy under fixed and flexible exchange rates". Canadian Journal of Economics and Political Science, 29, 475-485.

Nyblom, J. (1989). "Testing for constancy of parameters over time". Journal of the American Statistical Association, 84, 85-104.

Obstfeld, M. (2019). "Global Dimensions of U.S. Monetary Policy". NBER Working Paper No. 26039. 
Obstfeld, M., Ostry, J. D., and M. S. Qureshi (2019). "A tie that binds: Revisiting the trilemma in emerging market economies". Review of Economics and Statistics, 101, 279-293.

Obstfeld, M., Shambaugh, J. C., and A. M. Taylor (2005). "The trilemma in history: tradeoffs among exchange rates, monetary policies, and capital mobility". Review of Economics and Statistics, 87, 423-438.

Pesaran, M. H., T. Schuermann, and S. M. Weiner (2004). "Modeling regional interdependencies using a global error-correcting macroeconometric model". Journal of Business E Economic Statistics, 22, 129-162.

Ploberger, W., and W. Krämer (1992). "The CUSUM test with OLS residuals". Econometrica, 60, 271-286.

Quandt, R. (1960). "Tests of the hypothesis that a linear regression system obeys two separate regimes". Journal of the American Statistical Association, 55, 324-330.

Rey, H. (2013). "Dilemma not trilemma: the global cycle and monetary policy independence". In Proceedings-Economic Policy Symposium-Jackson Hole. Federal Reserve Bank of Kansas City.

Rey, H. (2016). "International channels of transmission of monetary policy and the Mundellian trilemma". IMF Economic Review, 64, 6-35.

Shambaugh, J. C. (2004). "The Effect of Fixed Exchange Rates on Monetary Policy". The Quarterly Journal of Economics, 119, 301-352.

Shin, H. S. (2015). Remarks at the Board of Governors of the Federal Reserve System conference "Monetary policy implementation and transmission in the post-crisis period". Washington DC, 13 November 2015.

Stock, J. H., and M. W. Watson (2002). "Forecasting using principal components from a large number of predictors" Journal of the American Statistical Association, 97, 11671179. 
Woodford, M. (2012). "Methods of Policy Accommodation at the Interest-rate Lower Bound" Jackson Hole symposium, August, Federal Reserve Bank of Kansas City.

Wu, J. C., and F. D. Xia (2016). "Measuring the macroeconomic impact of monetary policy at the zero lower bound" Journal of Money, Credit and Banking, 48, 253-291. 


\section{A Other Tables and Figures}

Table 4: Data availability for each country-specific model

\begin{tabular}{|c|c|c|c|c|c|c|c|}
\hline & $\begin{array}{l}\text { Output } \\
\text { growth }\end{array}$ & Inflation & $\begin{array}{l}\text { Short-term } \\
\text { rate }\end{array}$ & $\begin{array}{c}\text { Term } \\
\text { spread }\end{array}$ & NEER & $\begin{array}{l}\text { Real equity } \\
\text { prices }\end{array}$ & $\begin{array}{c}\text { Gross capital } \\
\text { inflows }\end{array}$ \\
\hline Argentina & $\mathrm{X}$ & $\mathrm{X}$ & $\mathrm{X}$ & & $\mathrm{X}$ & $\mathrm{X}$ & $\mathrm{X}$ \\
\hline Australia & $\mathrm{X}$ & $\mathrm{X}$ & $\mathrm{X}$ & $\mathrm{X}$ & $\mathrm{X}$ & $\mathrm{X}$ & $\mathrm{X}$ \\
\hline Brazil & $\mathrm{X}$ & $\mathrm{X}$ & $\mathrm{X}$ & & $\mathrm{X}$ & $\mathrm{X}$ & $\mathrm{X}$ \\
\hline Canada & $\mathrm{X}$ & $\mathrm{X}$ & $\mathrm{X}$ & $\mathrm{X}$ & $\mathrm{X}$ & $\mathrm{X}$ & $\mathrm{X}$ \\
\hline Chile & $\mathrm{X}$ & $\mathrm{X}$ & $\mathrm{X}$ & & $\mathrm{X}$ & $\mathrm{X}$ & $\mathrm{X}$ \\
\hline China & $\mathrm{X}$ & $\mathrm{X}$ & $\mathrm{X}$ & & $\mathrm{X}$ & & $\mathrm{X}$ \\
\hline Euro area & $\mathrm{X}$ & $\mathrm{X}$ & $\mathrm{X}$ & $\mathrm{X}$ & $\mathrm{X}$ & $\mathrm{X}$ & $\mathrm{X}$ \\
\hline India & $\mathrm{X}$ & $\mathrm{X}$ & $\mathrm{X}$ & $\mathrm{X}$ & $\mathrm{X}$ & $\mathrm{X}$ & $\mathrm{X}$ \\
\hline Indonesia & $\mathrm{X}$ & $\mathrm{X}$ & $\mathrm{X}$ & & $\mathrm{X}$ & & $\mathrm{X}$ \\
\hline Japan & $\mathrm{X}$ & $\mathrm{X}$ & $\mathrm{X}$ & $\mathrm{X}$ & $\mathrm{X}$ & $\mathrm{X}$ & $\mathrm{X}$ \\
\hline Korea & $\mathrm{X}$ & $\mathrm{X}$ & $\mathrm{X}$ & $\mathrm{X}$ & $\mathrm{X}$ & $\mathrm{X}$ & $\mathrm{X}$ \\
\hline Malaysia & $\mathrm{X}$ & $\mathrm{X}$ & $\mathrm{X}$ & & $\mathrm{X}$ & $\mathrm{X}$ & $\mathrm{X}$ \\
\hline Mexico & $\mathrm{X}$ & $\mathrm{X}$ & $\mathrm{X}$ & & $\mathrm{X}$ & $\mathrm{X}$ & $\mathrm{X}$ \\
\hline New Zealand & $\mathrm{X}$ & $\mathrm{X}$ & $\mathrm{X}$ & $\mathrm{X}$ & $\mathrm{X}$ & $\mathrm{X}$ & $\mathrm{X}$ \\
\hline Norway & $\mathrm{X}$ & $\mathrm{X}$ & $\mathrm{X}$ & $\mathrm{X}$ & $\mathrm{X}$ & $\mathrm{X}$ & $\mathrm{X}$ \\
\hline Peru & $\mathrm{X}$ & $\mathrm{X}$ & $\mathrm{X}$ & & $\mathrm{X}$ & & $\mathrm{X}$ \\
\hline Philippines & $\mathrm{X}$ & $\mathrm{X}$ & $\mathrm{X}$ & & $\mathrm{X}$ & $\mathrm{X}$ & $\mathrm{X}$ \\
\hline Saudi Arabia & $\mathrm{X}$ & $\mathrm{X}$ & & & $\mathrm{X}$ & & $\mathrm{X}$ \\
\hline Singapore & $\mathrm{X}$ & $\mathrm{X}$ & $\mathrm{X}$ & & $\mathrm{X}$ & $\mathrm{X}$ & $\mathrm{X}$ \\
\hline South Africa & $\mathrm{X}$ & $\mathrm{X}$ & $\mathrm{X}$ & $\mathrm{X}$ & $\mathrm{X}$ & $\mathrm{X}$ & $\mathrm{X}$ \\
\hline Sweden & $\mathrm{X}$ & $\mathrm{X}$ & $\mathrm{X}$ & $\mathrm{X}$ & $\mathrm{X}$ & $\mathrm{X}$ & $\mathrm{X}$ \\
\hline Switzerland & $\mathrm{X}$ & $\mathrm{X}$ & $\mathrm{X}$ & $\mathrm{X}$ & $\mathrm{X}$ & $\mathrm{X}$ & $\mathrm{X}$ \\
\hline Thailand & $\mathrm{X}$ & $\mathrm{X}$ & $\mathrm{X}$ & & $\mathrm{X}$ & $\mathrm{X}$ & $\mathrm{X}$ \\
\hline Turkey & $\mathrm{X}$ & $\mathrm{X}$ & $\mathrm{X}$ & & $\mathrm{X}$ & $\mathrm{X}$ & $\mathrm{X}$ \\
\hline United Kingdom & $\mathrm{X}$ & $\mathrm{X}$ & $\mathrm{X}$ & $\mathrm{X}$ & $\mathrm{X}$ & $\mathrm{X}$ & $\mathrm{X}$ \\
\hline United States & $\mathrm{X}$ & $\mathrm{X}$ & $\mathrm{X}$ & $\mathrm{X}$ & $\mathrm{X}$ & $\mathrm{X}$ & $\mathrm{X}$ \\
\hline
\end{tabular}

Notes: quarterly data, 1994Q1-2016Q4. Data are from the GVAR Quarterly Database recently updated in Mohaddes and Raissi (2018), with the exception of equity prices in Brazil, Mexico, and Turkey which are from the OECD Main Economic Indicators, and of gross capital inflows, whose data come from the IMF Balance of Payments Statistics. 
Figure 11: Accounting for the effective lower bound of US policy rate
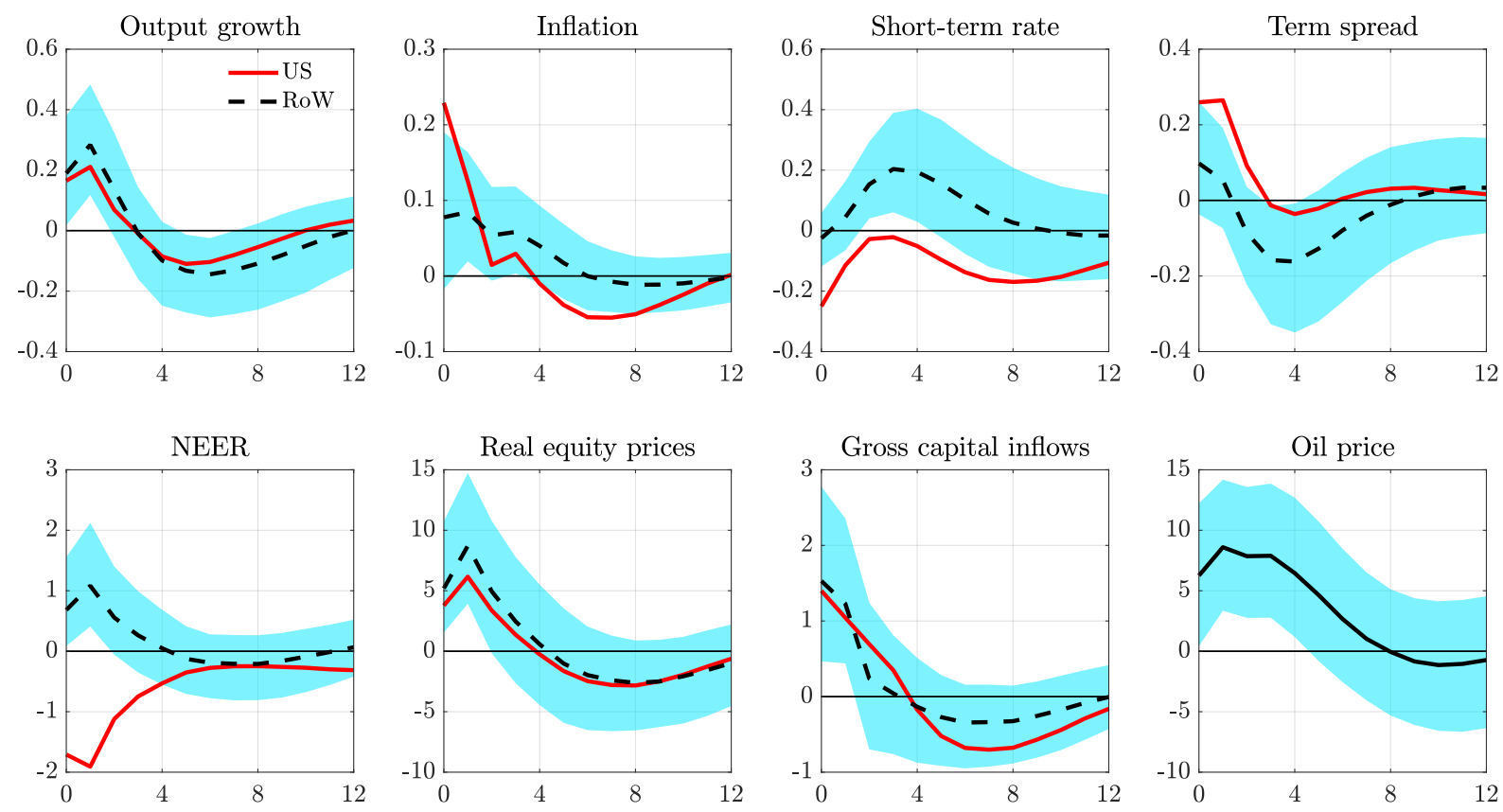

(a) US shadow rate
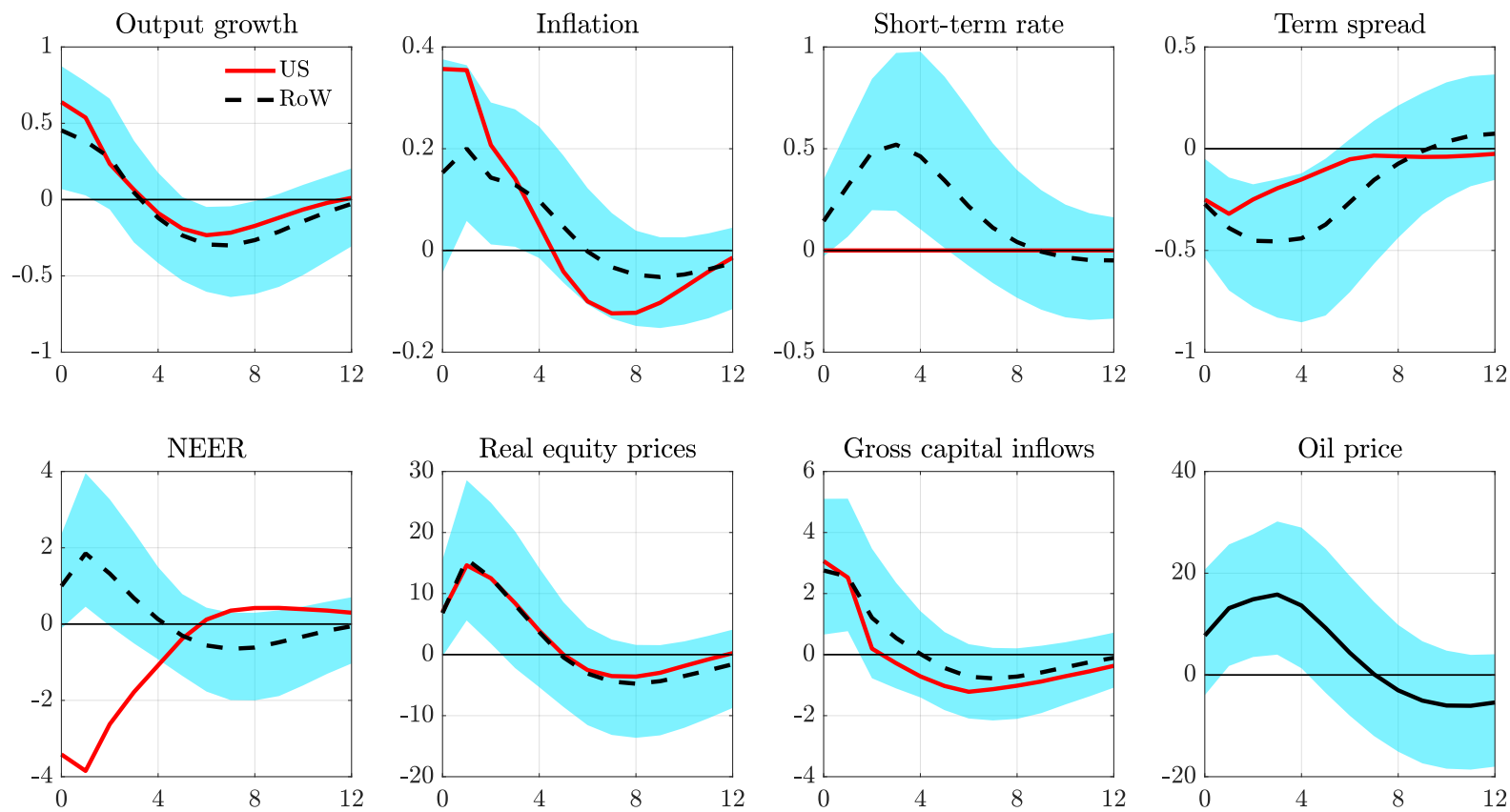

(b) ZLB on US short-rate

Notes: median responses for the rest of the world in dashed black, joint with 16th and 84th percentiles, and median responses for the US in solid red, to an expansionary US monetary policy shock which either decreases on impact the US shadow rate of Wu and Xia (2016) by 25 basis points (panel a), or decreases on impact the US term spread by 25 basis points while at the same time imposing that the US short-term interest rate cannot move over three years from the shock (panel b). $x$ and $y$ axes measure quarters and percentage points, respectively. 
Figure 12: Exchange rate and spillovers, high capital controls countries
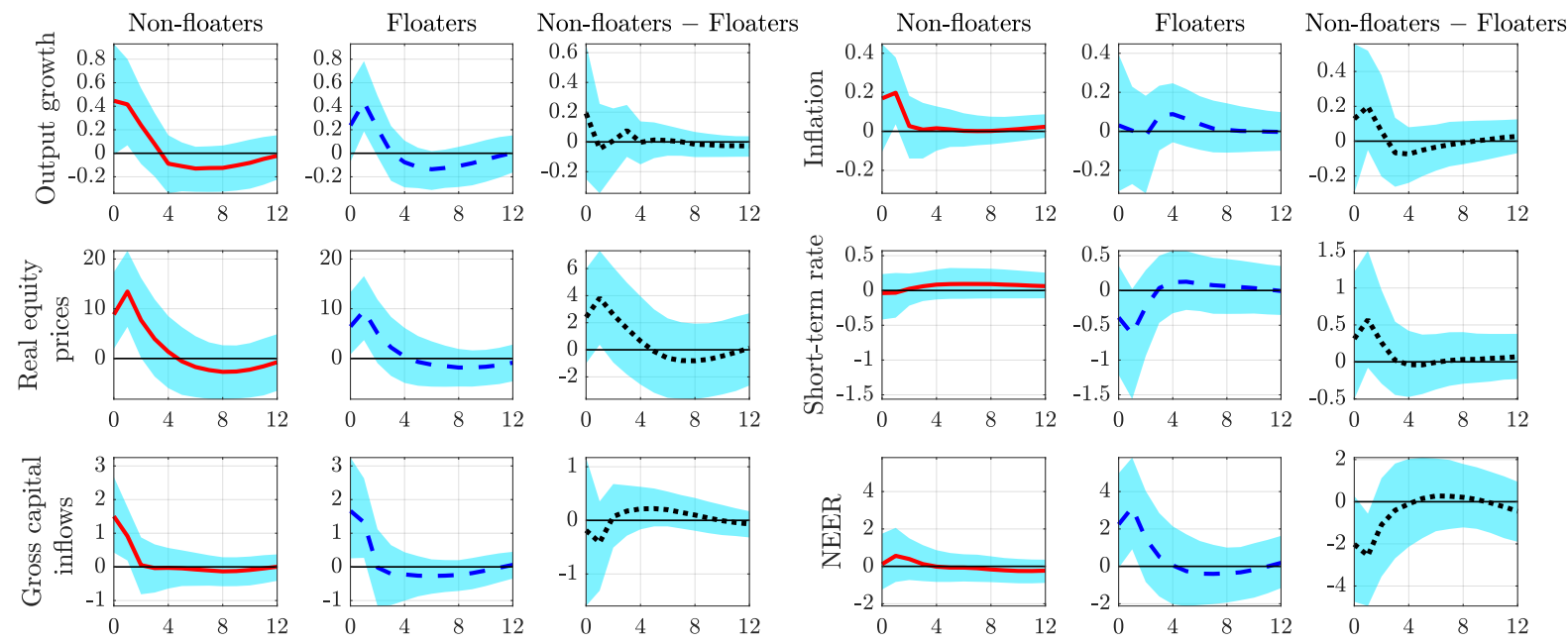

(a) Drop of US policy rate
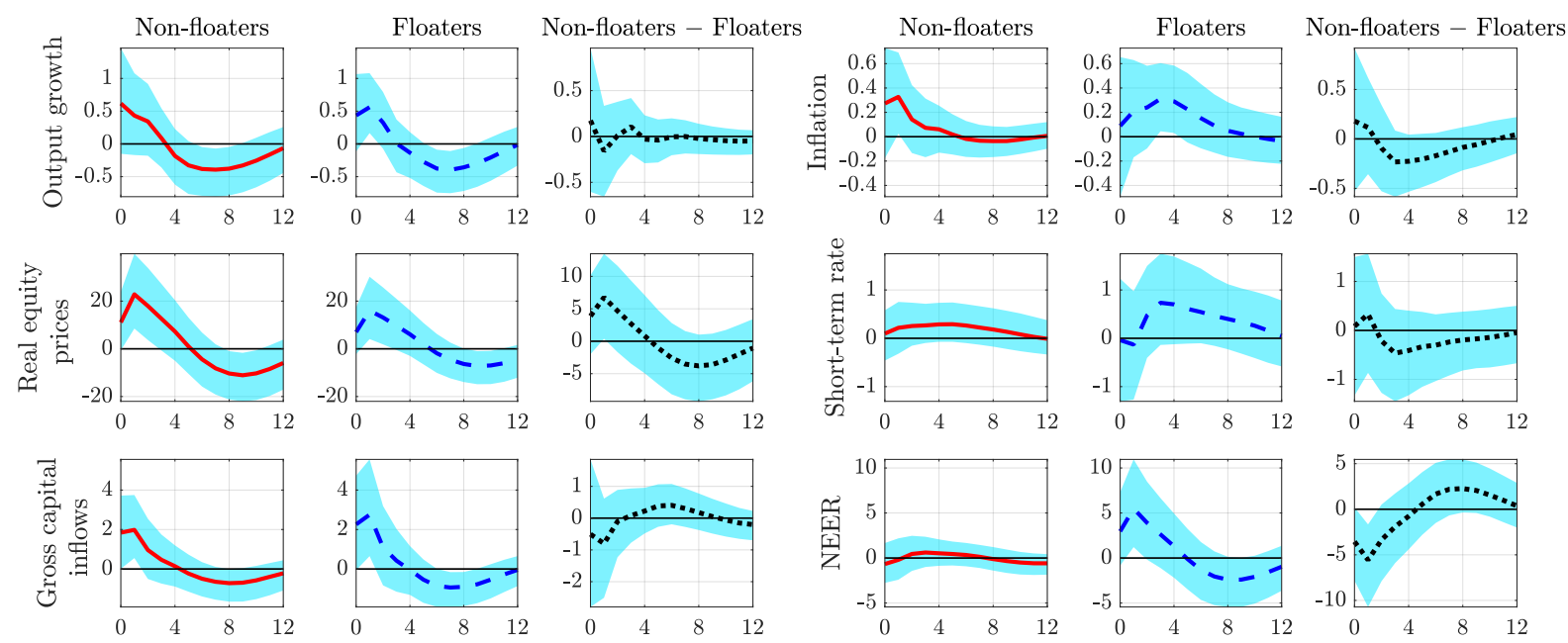

(b) Compression of US term spread

Notes: median responses joint with 16th and 84th percentiles for the high capital controls non-floaters (solid red), floaters (dashed blue), and their discrepancy (dotted black), to an expansionary US monetary policy shock which either decreases on impact the US short-term rate by 25 basis points (panel a), or which decreases on impact the US term spread by 25 basis points (panel b). $x$ and $y$ axes measure quarters and percentage points, respectively. 
Figure 13: Exchange rate and spillovers, low capital controls countries
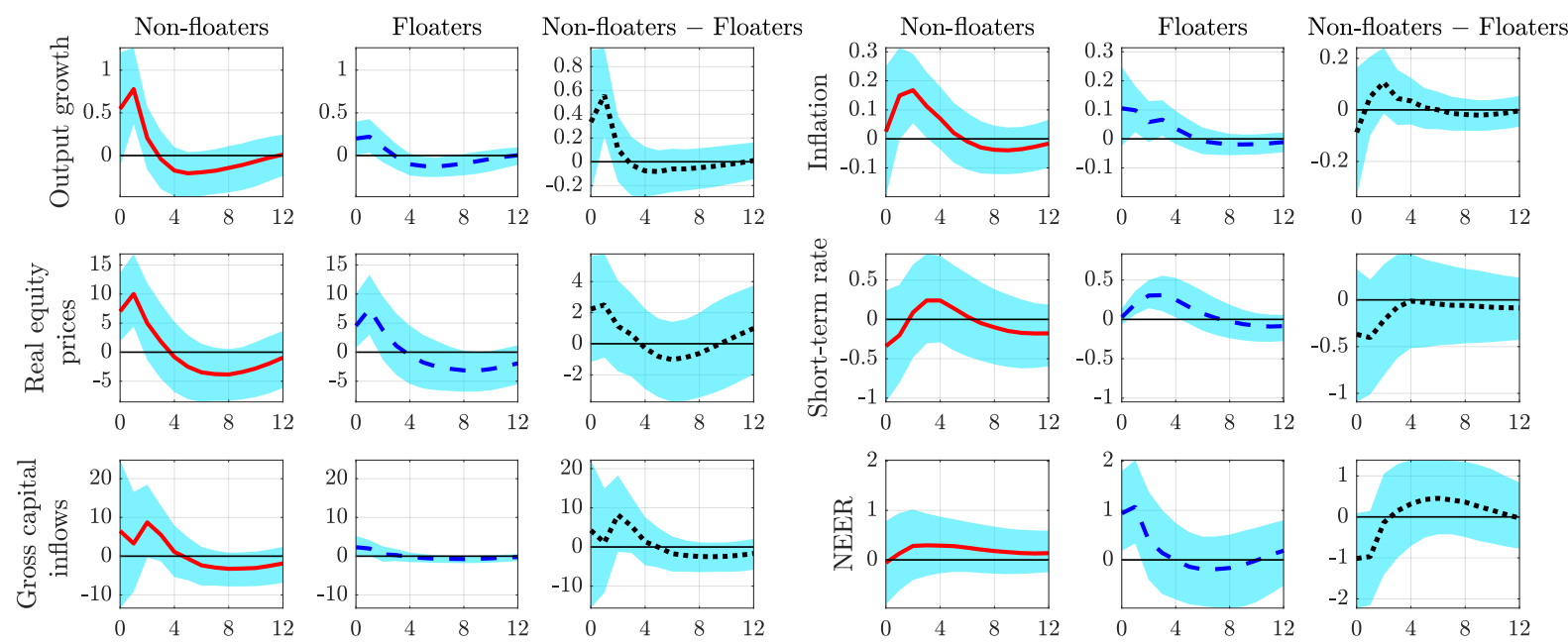

(a) Drop of US policy rate
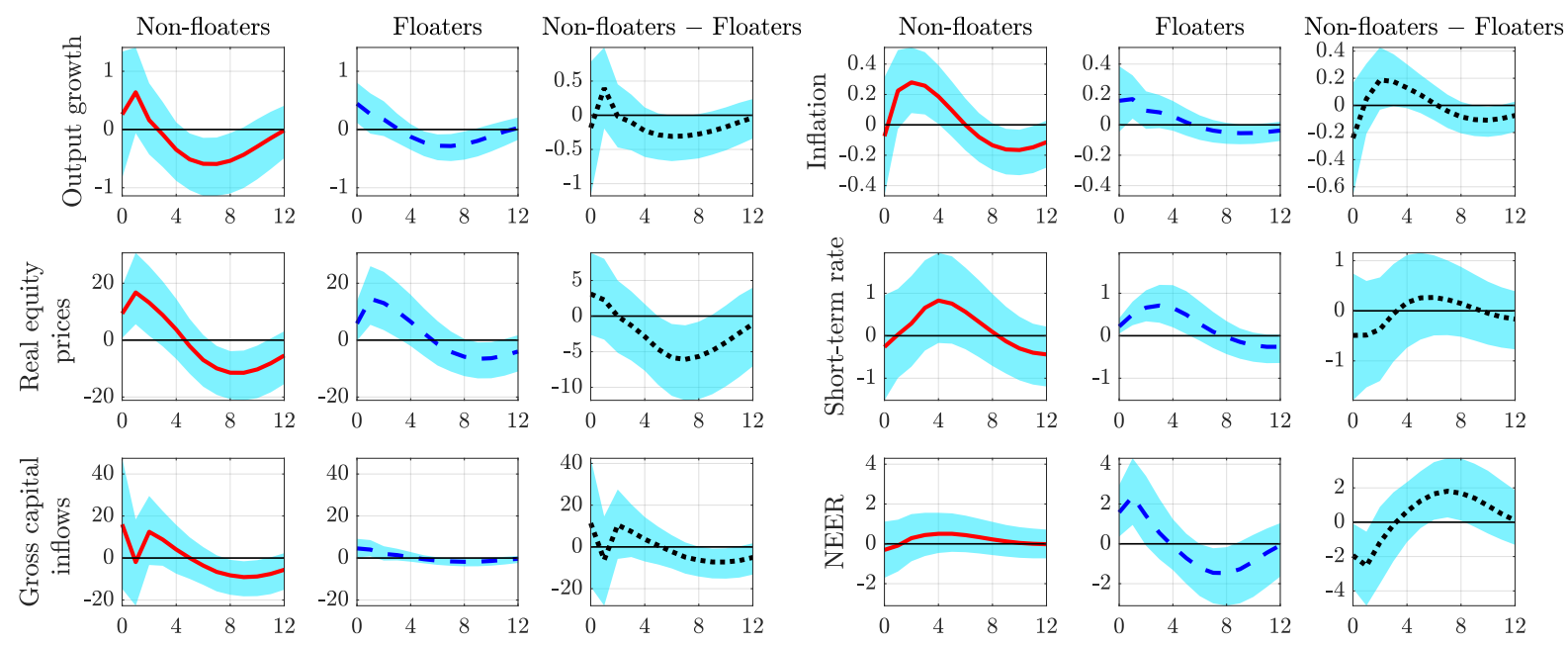

(b) Compression of US term spread

Notes: median responses joint with 16th and 84th percentiles for the low capital controls non-floaters (solid red), floaters (dashed blue), and their discrepancy (dotted black), to an expansionary US monetary policy shock which either decreases on impact the US short-term rate by 25 basis points (panel a), or which decreases on impact the US term spread by 25 basis points (panel b). $x$ and $y$ axes measure quarters and percentage points, respectively. 
Figure 14: Spillover, network, and direct effects of US monetary policy shocks
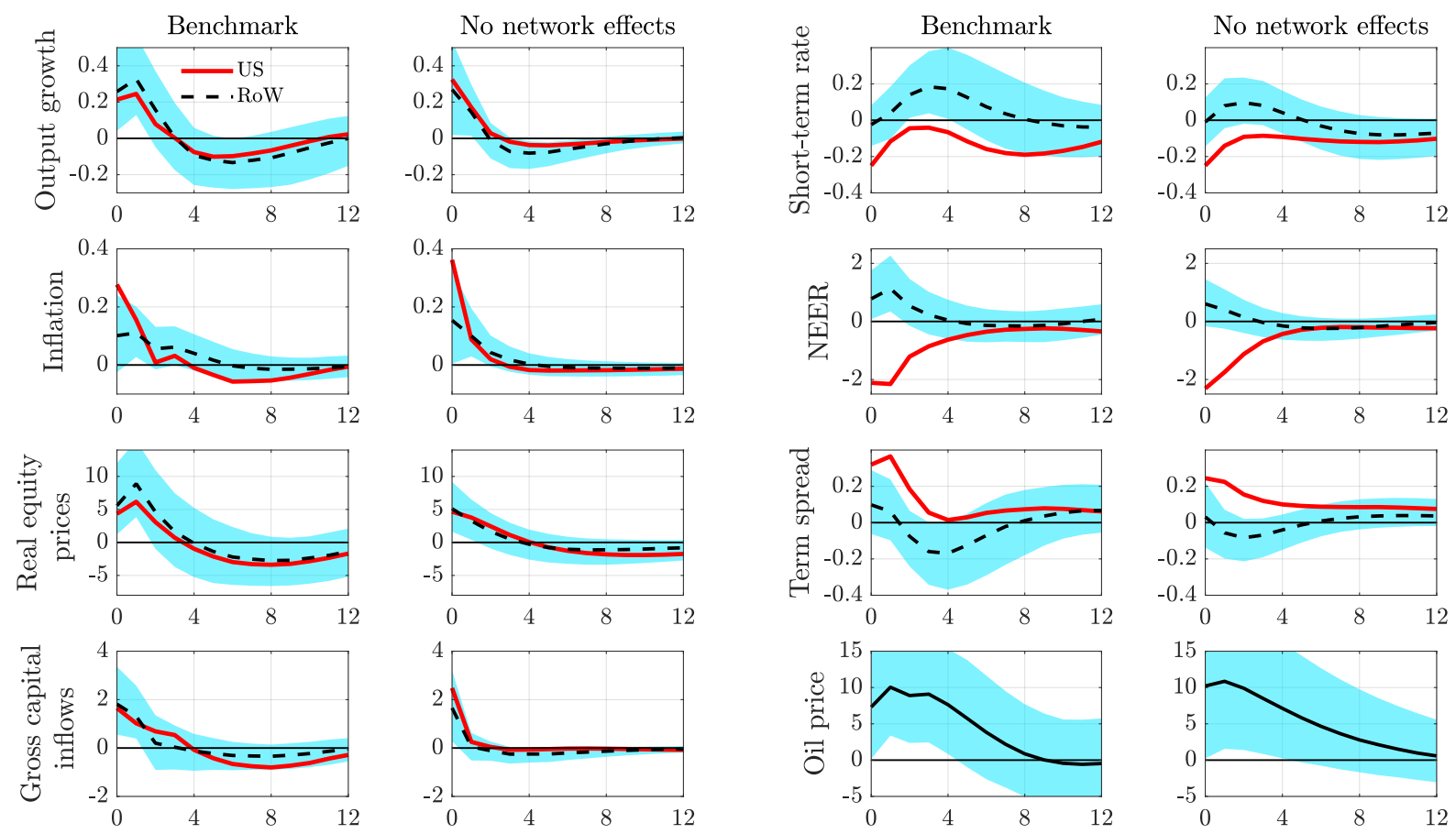

(a) Drop of US policy rate
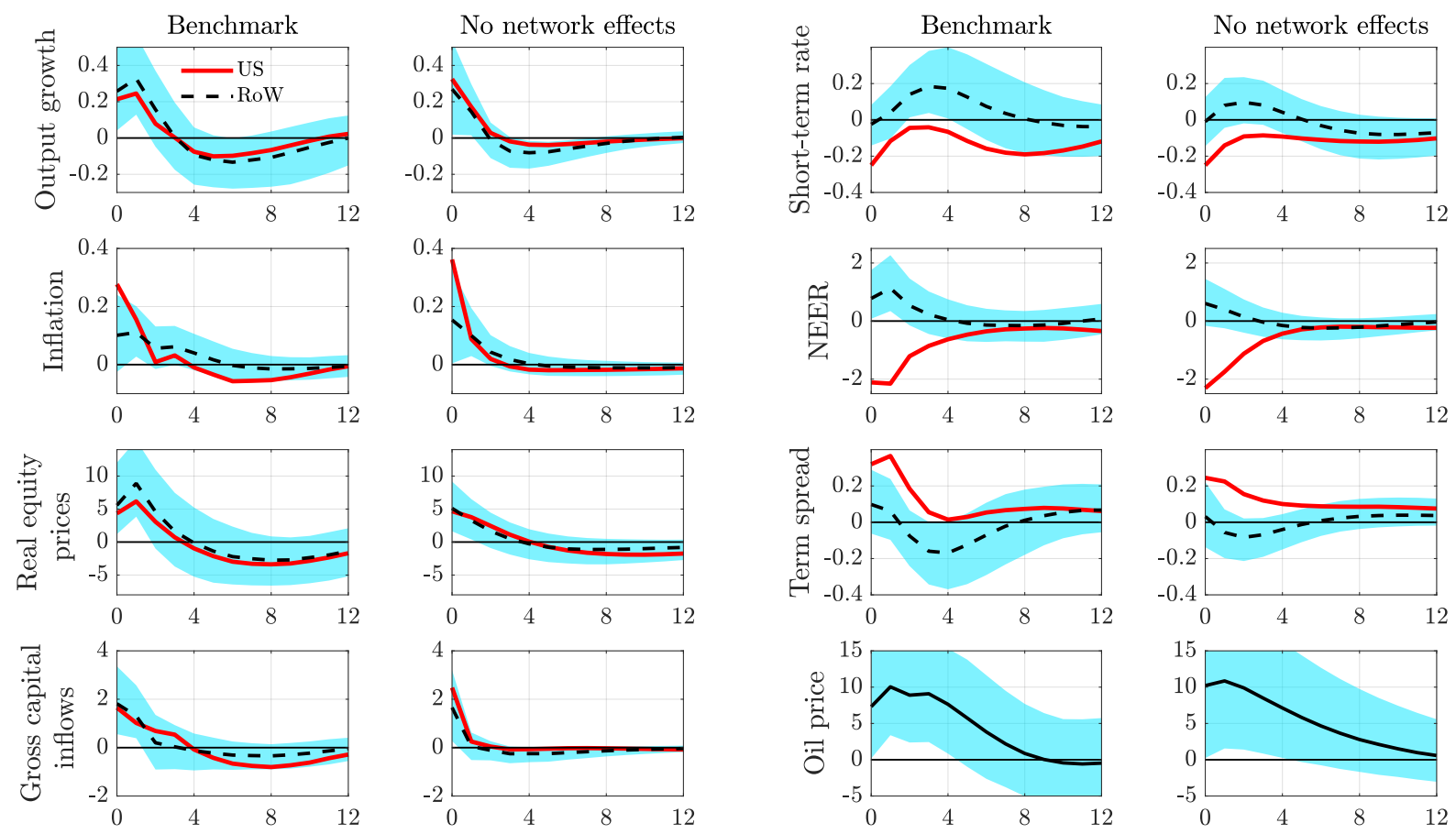

(b) Compression of US term spread

Notes: median responses for the rest of the world in dashed black line, joint with 16th and 84th percentiles, and median responses for the US in solid red, to an expansionary US monetary policy shock which either decreases on impact the US short-term rate by 25 basis points (panel a) or decreases on impact the US term spread (panel b), for the baseline model (Benchmark) and for an alternative model which precludes network effects (No network). $x$ and $y$ axes measure quarters and percentage points, respectively. 